\title{
+-Evidence of Porphyry Deposits in the Ntem Complex: A Case Study from Structural and Hydrothermal Alteration Zones Mapping through Landsat-8 0LI, Aeromagnetic and Geological Data Integration in the Yaounde-Sangmelima Region (Southern Cameroon)
}

\author{
Stephane Patrick Assembe ${ }^{1,2 *}$, Theophile Ndougsa Mbarga ${ }^{3 *}$, Françoise Enyegue A. Nyam ${ }^{4}$, \\ Paul Claude Ngoumou ${ }^{5}$, Arsene Meying 5 , Daniel Herve Gouet ${ }^{6}$, Alain Zanga ${ }^{7}$, Jean Daniel Ngoh ${ }^{1}$ \\ ${ }^{1}$ Postgraduate School of Technology, Science and Geoscience, University of Yaounde 1, Yaounde, Cameroon \\ ${ }^{2}$ Department of Physics, Faculty of Science, University of Bamenda, Bambili, Cameroon \\ ${ }^{3}$ Department of Physics, Higher Teachers Training College, University of Yaounde 1, Yaounde, Cameroon \\ ${ }^{4}$ Department of Physics, Faculty of Science, University of Yaounde 1, Yaounde, Cameroon \\ ${ }^{5}$ School of Geology and Mining Engineering, University of Ngaoundere, Meiganga, Cameroon \\ ${ }^{6}$ Faculty of Mining and Petroleum Industries, University of Maroua, Kaele, Cameroon \\ ${ }^{7}$ Department of Physics, Faculty of Science, University of Douala, Douala, Cameroon \\ Email: *assembest@yahoo.fr, *tndougsa@yahoo.fr
}

How to cite this paper: Assembe, S.P., Mbarga, T.N., Nyam, F.E.A., Ngoumou, P.C., Meying, A., Gouet, D.H., Zanga, A. and Ngoh, J.D. (2020) +-Evidence of Porphyry Deposits in the Ntem Complex: A Case Study from Structural and Hydrothermal Alteration Zones Mapping through Landsat-8 OLI, Aeromagnetic and Geological Data Integration in the Yaounde-Sangmelima Region (Southern Cameroon). Advances in Remote Sensing, 9, 53-84.

https://doi.org/10.4236/ars.2020.92004

Received: January 26, 2020

Accepted: June 5, 2020

Published: June 8, 2020

\begin{abstract}
A semi-regional study was carried out in the Yaounde-Sangmelima area, a densely vegetated tropical region of southern Cameroon located in the Central Africa Fold Belt (CAFB)/Congo Craton (CC) transition zone. Towards structural lineaments and predictive hydrothermal porphyry deposits mapping, an integrated analysis of Landsat-8 OLI data, aeromagnetic, geological and mineral indices maps was performed. The Remote sensing using False colour composite images involving bands combinations and Crosta method (features oriented principal components analysis) enabled the mapping of the gneisses and schists domains without a clear differentiation between the Yaounde and Mbalmayo schists; despite the reflectance anomalies evidenced NW of Akonolinga, hydrothermal alterations in the study area failed to be detected. Besides, aeromagnetics depicted a moderately fractured northern zone (the CAFB) contrasting with a high densely fractured zone (the CC,
\end{abstract}


Copyright (c) 2020 by author(s) and Scientific Research Publishing Inc. This work is licensed under the Creative Commons Attribution International License (CC BY 4.0).

http://creativecommons.org/licenses/by/4.0/

Open Access known as Ntem complex). The Ntem complex displays signatures of a meta-igneous, an intrusive complex, greenstone relics south of Sangmelima and hydrothermal activity. Indeed, CET porphyry analysis tool detected many porphyry centres. In general, the study revealed many lineaments including contacts, fractures faults zones and strike-slips. The major aeromagnetics structures are SW-NE to WSW-ENE and WNW-ESE to NW-SE while those from Landsat-8 are NE-SW, WNW-ESE, NW-SE, WSW-ENE and NW-ESE to NNW-SSE. Together, these structures depict trans-compressions or trans-tensions corresponding to a broad NE-SW strike-slips channel that affect both the CAFB and the Ntem Complex, and they control the intrusions thus confirming a pervasive hydrothermal activity within the Ntem Complex. The proximity or coincidence of these porphyry centres with some mapped Iron-Gold affiliated mineral indices and porphyry granites indicate the possible occurrence of many hydrothermal ore deposits. These results show the high probability for the Ntem complex to host porphyry deposits so they may serve to boost mineral exploration in the Yaounde-Sangmelima region and in the entire southern Cameroon as well.

\section{Keywords}

Porphyry Centres, Hydrothermal Ore Deposits, Ntem Complex, Remote sensing, Aeromagnetics, Southern Cameroon

\section{Introduction}

Hydrothermalism alters rocks and provokes various types of mineralization occurring in general as polymetallic deposits (e.g. (IOCG; porphyry $\mathrm{Cu}-\mathrm{Au}$ ) $+/-$ $\mathrm{Ag}, \mathrm{U}, \mathrm{Mo}, \mathrm{Pb}, \mathrm{REE}, \mathrm{Zn}$, etc). Most common hydrothermal deposits styles are intrusion related, epithermal, skarns and porphyry [1] [2] [3]. In general, porphyry deposits are hosted in Archaean to Proterozoic terrains in a convergent setting [2] [4] [5] [6]. The CAFB/CC transition zone in southern Cameroon, at the northern margin of the Congo craton (CC), in regards to its geological history, becomes good candidate host of these deposit types. Therefore, a detailed geoscience work needs to be done in this region, to assess this potential and subsequently revamp mineral exploration industry.

Remote sensing (RS) and aeromagnetics are solutions to geoscientific studies in wide and inaccessible regions. in geological RS, surface alteration controls better the reflectance of geologic materials so, high discrimination capabilities of lithology are found in the visible near infrared-VNIR and Shortwave infrared (SWIR) regions i.e. 0.7 to $3.0 \mu \mathrm{m}$ interval [7] [8]. Various pre-processing and processing technique/enhancement workflows exist and are intuitively used to meet desired goals. However, the most common approaches involve whether alone or in combination, bands combination, band rationing, data dimensional reduction and image filtering (e.g. see, [8] [9] for detailed discussions). RS has become a standard tool in geological studies by highlighting faults/fractures in 
structural studies [10] [11] [12] [13] [14] and in mapping lithology and/or hydrothermal alteration zones related to mineral ore deposits [15]-[20] in different geological contexts across continents. Some recent pioneer studies involving Landsat suites data have been done in Cameroon to address structural [21] hydrological [22] or lithology and mineral exploration [23] [24] [25] issues.

Aeromagnetics is a premium tool in geological and mineral exploration studies for its high capabilities in mapping structures and lithology irrespective of the terrain conditions and availability of outcrops at any scale [26] [27]. Various filtering and processing techniques have been developed for qualitative, quantitative or both, interpretation. Qualitative interpretation involves mostly the use of edge detection filters for lineaments detection and even specific features like porphyry and kimberlite bodies [27] [28] [29] [30]. Quantitative interpretation involves depth-to-basement (e.g. Euler deconvolution approaches by [31] [32]) and modelling methods which solve either or both the nature, location, shape and susceptibility of the source (e.g. see [33]). Significant contributions from aeromagnetics to update the geology of the CC/CAFB transition zone are being made by many workers [34] [35] [36], but most of these lack field evidences. In geophysics, the adjunction of at least two methods gives more consistent results; thus, we combine the strong mapping capabilities of aeromagnetics, RS so as to yield more accurate and credible results while investigating the Yaounde-Sangmelima region. The consistency of this approach has been proven by several workers (e.g. [14] [25] [37] [38]) who combined Landsat, aeromagnetic and geological data to map both hydrothermal targets, lithology and lineaments as well, in various geological contexts.

\section{Geological Setting}

The Yaounde-Sangmelima area is located in southern Cameroon, a region entirely dominated by the tropical dense forest with thick lateritic soil at the northern margin of the CC. The main lithological units are, southward, the CAFB and the Ntem complex (Figure 1(a)). according to [39] [40] [41], the Ntem complex comprises various Archaean to Paleoproterozoic rocks. Archaean formations are mainly tonalites [42] [43] [44]; calc-alkaline to alkaline granitoids and granodiorites in dominantly occurring charnockites, as well as greenstones relics [40] [45] [46] [47]. Moreover, [40] and [48] identified dolerite dykes, syenites, metabasites and gneisses as in the Nyong series as Paleoproterozoic. The CAFB regroups Neoproterozoic terranes overlying a Paleoproterozoic basement. According to [43] [49] [50] [51] (and references therein), the Neoproterozoic assemblages are: 1) dominantly garnetiferous gneisses and micaschists, amphibolites and some quartzites that form the granulitic Yaounde series; and 2) low-grade schists and quartz-sericite rocks associated with volcanic relics forming the Mbalmayo series discordant to the Ntem complex (Figure 1(b)).

The tectonic activity at the northern margin of the CC takes into consideration the difference in its lithological arrangement. Indeed, according to some 


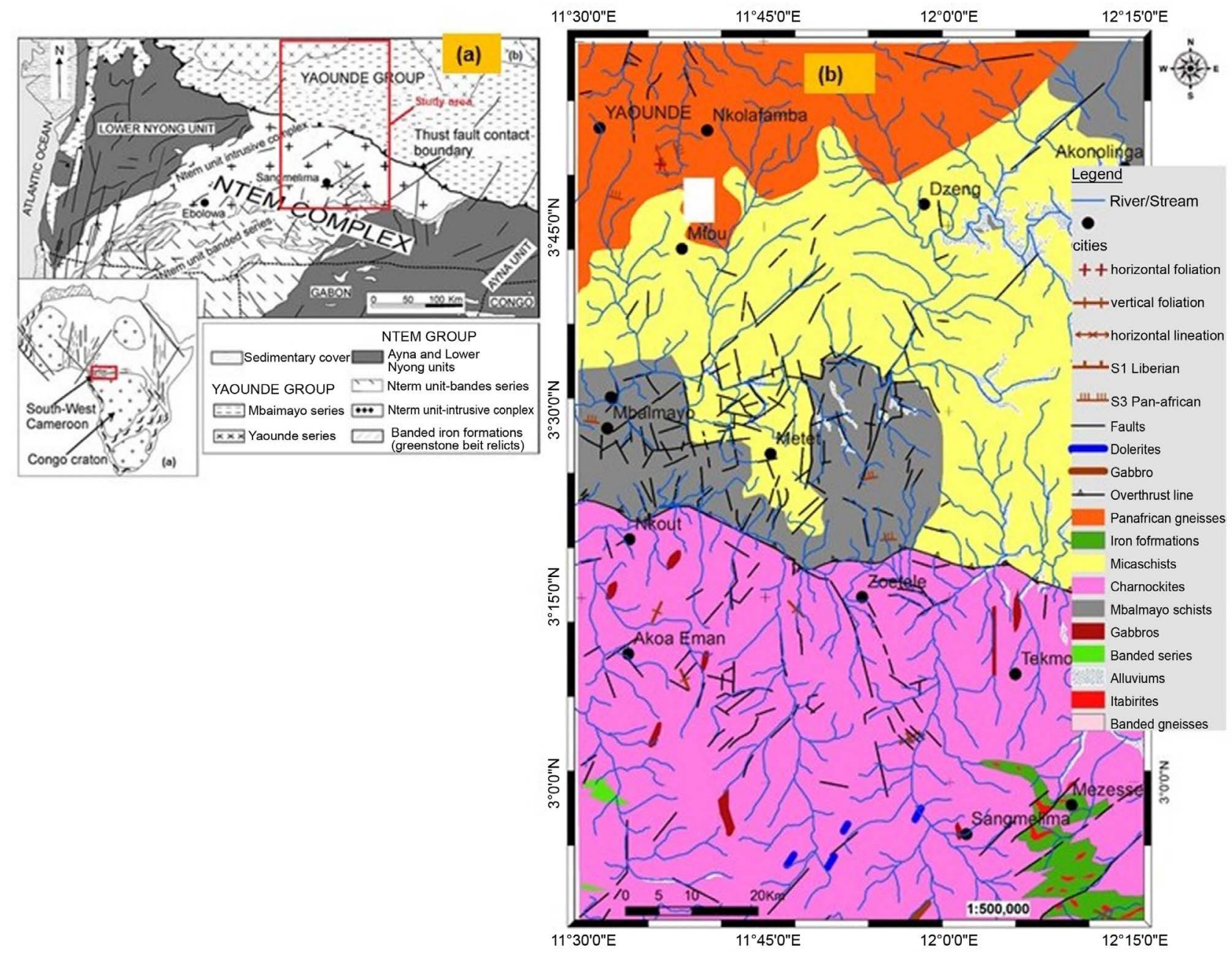

Figure 1. Local geological map of the Yaounde-Sangmelima after [42] [43].

workers the Ntem complex seems to have been first influenced by the Liberian orogeny marked by various folds and brittle structures [52] with an Archaean magmatism [45] [53]. The second main event in the Ntem complex is the Eburnean orogeny marking the Sao-Francisco Craton/Congo Craton collision [54] [55] during which NE-SW, E-W to ESE-WNW, NW-SE and N-S main lineaments formed and the crust rejuvenated at the NW edge of the CC [56] [57] [58] [59]. Obviously, this seems to be the more documented event affecting the cratonic part of the study area.

The CAFB besides is clearly affected by Panafrican and post-Panafrican tectonics. Previous studies identified four Panafrican deformation stages (e.g. [60] [61] [62]). In the Yaounde group, [63] summarised it into the thrusting of the CAFB nappes onto the followed by ENE-WSW strike-slips. These tectonics caused by overall dextral transpressions due to alternating E-W to NW-SE contractions and N-S to NE-SW orogenic-parallel extensions [62] generated N or S penetrative foliation associated with ENE-WSW stretching lineation and a N-S to NE-SW folding. However, this evolution is still debated (see e.g., [50] [64] [65] [66]), regarding the collisional system, the location and direction and the 
geodynamic history of the Yaounde domain. Despite some relevant interpretations of the faults/fractures that they discovered (see e.g. [67] [68]), most geophysical studies fail to reconcile the aforesaid matters as they don't propose structural history of the northern margin of the CC based at least on these mapped features. Also, insufficient geophysical works towards predictive mapping of the ore minerals potentialities in the $\mathrm{CAFB} / \mathrm{CC}$ transition zone have been done. This paper brings contributions to resolve the two above outstanding points through an integrated analysis of remote sensing, aeromagnetic and geological data over the Yaounde-Sangmelima region.

\section{Data and Methods}

\subsection{Geological Datasets}

The geological information used for this study comes from the official maps of the Republic of Cameroon that cover the Yaounde-Sangmelima area. To obtain a digital geological database, these maps were initially georeferenced, then warped in Google map for geographical rectification; then lithological, structural and mineral indices information was extracted through ArcGIS desktop 10.6.

\subsection{Remote Sensing Method}

\subsubsection{Data Description and Preparation}

The satellite data used are SRTM and Landsat 8 Operational Land Imager (OLI). SRTM are topographic data that model the elevation of a given surface relative to the sea level. They are availed as $1 \times 1$ degree scenes at a $30 \mathrm{~m}$ spatial resolution. OLI is a multispectral sensor on board of the Landsat 8 satellite whose bands characteristics are summarised in Table 1.

These are standard geometrically corrected (L1T1) images projected on the corresponding UTM zone freely available from the Global Land Cover Facility portal (http://earthexplorer.usgs.gov/). The current study uses two adjacent scenes whose respective path/row identifications are 185/057 and 185/058, recorded on the 12th January 2015 at approximately $09 \mathrm{~h} 45 \mathrm{~min}$. The two OLI scenes underwent a 3 -steps preparation pre-processing stage consisting in:

Table 1. Landsat 8 OLI images characteristics [68].

\begin{tabular}{cccc}
\hline Band Number & Spectral range $(\mu \mathrm{m})$ & Spectral band & Resolution \\
\hline 1 & $0.43-0.45$ & Coastal blue & $30 \mathrm{~m}$ \\
2 & $0.45-0.51$ & Blue & $30 \mathrm{~m}$ \\
3 & $0.53-0.59$ & Green & $30 \mathrm{~m}$ \\
4 & $0.64-0.67$ & Red & $30 \mathrm{~m}$ \\
5 & $0.85-0.88$ & NIR & $30 \mathrm{~m}$ \\
6 & $1.57-1.65$ & SWIR-1 & $30 \mathrm{~m}$ \\
7 & $2.11-2.29$ & SWIR-2 & $30 \mathrm{~m}$ \\
8 & $0.50-0.68$ & Panchromatic & $30 \mathrm{~m}$ \\
9 & $1.36-1.38$ & Cirrus & $30 \mathrm{~m}$ \\
\hline
\end{tabular}


1) The radiometric calibration for atmospheric correction to remove the influence of the atmosphere and haze, and conversion of digital numbers of each individual scene into surface reflectance which is physically meaningful for earth objects investigation. The operation was realised using the Quick atmospheric correction $\left(\mathrm{QUAC}^{\circledast}\right)$ which determines atmospheric correction parameters directly from the observed pixel spectra in a scene, without ancillary information.

2) Vegetation suppression by removing the signal related to the canopy on each individual scene in order to produce a multispectral image that mimics the surface reflectance without vegetation.

3) the mosaicking of the pre-processed scenes, then spatially subsetting the mosaicked image to the study area and reducing its spectral dimension by removing the coastal band (band 1) which is not useful in geology.

\subsubsection{Multispectral Images Processing Methods}

Colour composition. Colour composition is an image enhancement technique which consists in combining natural or hybrid bands (e.g. band ratios, eigenvectors, etc.). When using natural bands, the appropriate bands combinations were determined using the optimum index factor (OIF) initially designed by [69] statistically determines the most appropriate combinations represented by the highest OIF ranking as presented in Table 2.

These combinations were used to map the lithology of the Yaounde-Sangmelima area, by undelaying the SRTM map to identify changes in texture (Figure 2(a)).

Principal components (PC) analysis. The PC transform segregates noise components, decorrelates and reduces the dimensionality of data sets. The dimensionality reduction removes the redundancy in the dataset, yielding uncorrelated hybrids bands (PC bands) which concentrate maximum information from the multispectral data. [70] developed a feature-oriented PC (FPCS) approaches to focus on specific goals (minerals). The principle consists in the calculation of PCs from a specific group of bands containing information on the sought feature then select the most informative FPC band. The FPCS were calculated in the bands $(2,3,4,5)$ for iron oxides and hydroxides detection; and in the bands $(4,5,6,7)$ for clays $(\mathrm{OH})$. The resulting FPCS are presented in Table 3.

Lineaments extraction. To map lineaments, the greyscaled standard PC1 image is high-pass filtered using a $3 \times 3$ window to reduce noise and enhance

Table 2. OIF ranking showing the highest five statistically convenient FCC images.

\begin{tabular}{cccc}
\hline & \multicolumn{2}{c}{ OIF Highest ranking } & \\
\hline Band 7 & Band 6 & Band 2 & 0.51 \\
Band 7 & Band 6 & Band 3 & 0.47 \\
Band 7 & Band 5 & Band 2 & 0.44 \\
Band 6 & Band 5 & Band 2 & 0.42 \\
Band 6 & Band 3 & Band 2 & 0.38 \\
\hline
\end{tabular}



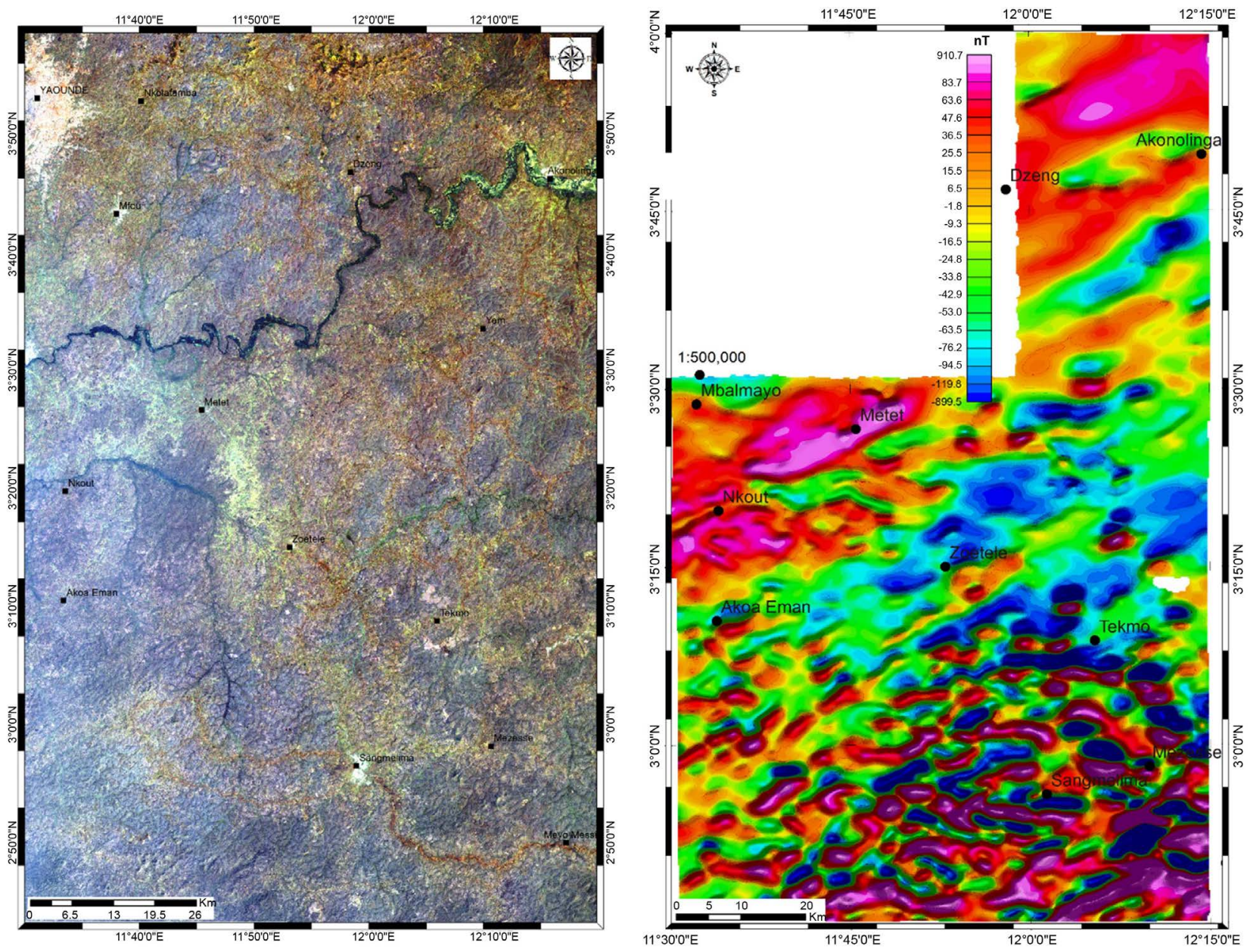

Figure 2. (a) Natural colour composite (RGB432) with the vegetation suppressed. The image mimics the soil surface reflectance. (b) Magnetic anomaly field reduced to the equator. The map has a NE anomaly passing through Metet depicting a discontinuity affecting both the CAFB and the Ntem Complex.

Table 3. Feature-oriented PCs for respectively clays (PCOH) and iron (PCFe) oxides/hydroxide minerals.

(a)

\begin{tabular}{lcccc}
\hline & & PCOH & \\
\hline & Band 2 & Band 5 & Band 6 & Band 7 \\
\hline PCOH1 & 0.246 & 0.412 & 0.578 & 0.660 \\
PCOH2 & 0.887 & 0.259 & -0.174 & -0.339 \\
PCOH3 & 0.389 & -0.826 & -0.042 & 0.407 \\
PCOH4 & -0.036 & 0.285 & -0.796 & 0.532 \\
\hline
\end{tabular}

(b)

\begin{tabular}{lcccc}
\hline & & PCFe & \\
\hline & Band 2 & Band 3 & Band 4 & Band 5 \\
\hline PCFe1 & 0.521 & 0.471 & 0.501 & 0.506 \\
PCFe 2 & 0.763 & -0.067 & -0.086 & -0.638 \\
PCFe 3 & 0.382 & -0.456 & -0.555 & 0.581 \\
PCFe 4 & -0.026 & -0.752 & 0.658 & 0.022 \\
\hline
\end{tabular}


edges. The filtering is performed on Envi 5.3 platform. The features extraction involved a semi-supervised classification that consists in 1) automatically detect lineaments from the high-pass filtered image of PC1 using the Canny edge filter within the LINE module in PCI-Geomatica 9.0 software. Later, 2) the image of the computer extracted features is underlain by the digital elevation model generated from the SRTM data above the area, to manually extract the lineaments using the photo-geological approach.

\subsection{The Magnetic Method}

\subsubsection{Data Description and Preparation}

The study utilises aeromagnetic data collected in January 1970 during a nationwide campaign held in Cameroon. The flight paths flown at a nominal altitude of $235 \mathrm{~m}$, were spaced at $750 \mathrm{~m}$ and oriented S-N. major equipment consisted in a radar altimeter of $20 \mathrm{~m}$ precision. The field data were processed by Paterson Ltd and availed as total field maps at 1/50,000 scale. The total magnetic intensity (TMI) anomaly field was obtained by removing the geomagnetic field that pertained in 1970; assuming a mean declination of $-18.2^{\circ}$ and a mean inclination of $-6.2^{\circ}$, Reduction-to-the magnetic equator (RTE) transform was applied to the anomaly field to shift anomalies on top of their sources [29]. The resultant RTE map (Figure 2(b)) served as input for further analyses.

\subsubsection{Magnetic Data Processing and Interpretation}

Analytic signal method. The analytic signal (AS) is formed through the combination of horizontal and vertical gradients of a potential field [29]. Introduced by [71] to solve the depth and position of the anomaly sources in the $2 \mathrm{D}$ case, [72] extended the method to solve 3D problems on gridded data. The AS is used either as a mapping and depth-to source technique and as a way to learn about the nature of the causative magnetization [30].

The horizontal gradient method. The horizontal gradient method (HGM) is in many ways the simplest approach to estimate contact locations of the bodies at depth and it is advantageously less sensitive to the noise in the data because it only requires calculations of the two first-order horizontal derivatives of the field [29]. The HGM function gives a peak anomaly above magnetic sources which will be interpreted as lineaments [30] [73]; HGM peaks can be evaluated at different the upward continued heights, leading to a multiscale analysis [74]. The multiscale HGM is commonly has been used in lineaments mapping by several workers using magnetic or gravity data in structural investigations [27] [75] [76] [77].

CET Porphyry analysis. The CET Porphyry analysis tool was developed by the Centre for Exploration Targeting (CET), an Australian research group addressing mineral exploration industry problems. Developed by [78], this tool relies on the fact that an ideal porphyry hydrothermal mineralisation typically appears as a circular central intrusion surrounded by concentric circular alteration zones. The detection process involves sequentially applying: 1) the circular feature transform which uses a radial symmetry transform algorithm to detect cir- 
cular shaped (elevated or depressed) features by identifying where image gradients converge or diverge respectively. 2) Performing central peak detection; and then visualising the feature boundaries using the amplitude contrast transform and the boundary tracing using a spline energy function that specifies porphyry boundaries.

The preparation and processing of Landsat 8 data was done in Envi 5.3 and lineament were automatically extracted with PCI-Geomatica v9.0; all the magnetic data preparation and processing was done in Oasis montaj 8.4. Maps were finalised and edited with ArcGIS 10.6 and Rockworks 16 served to draw lineaments rosaceas.

The work methodology consisted in detecting key lithology, zone of hydrothermal activity and lineaments from remote sensing and aeromagnetics, separately; then making a fusion and cross-validation of the results between the two methods at a first stage, and the final outputs are validated by the available geological data to yield the more plausible map of structural lineaments and porphyry deposits in the study area. This methodology is summarised by the flowchart (Figure 3).

\section{Results}

\subsection{Lithology Mapping}

\subsubsection{Colour Composite Images Analyses}

The true colour composition (Figure 2(a)) makes it difficult to outline specific

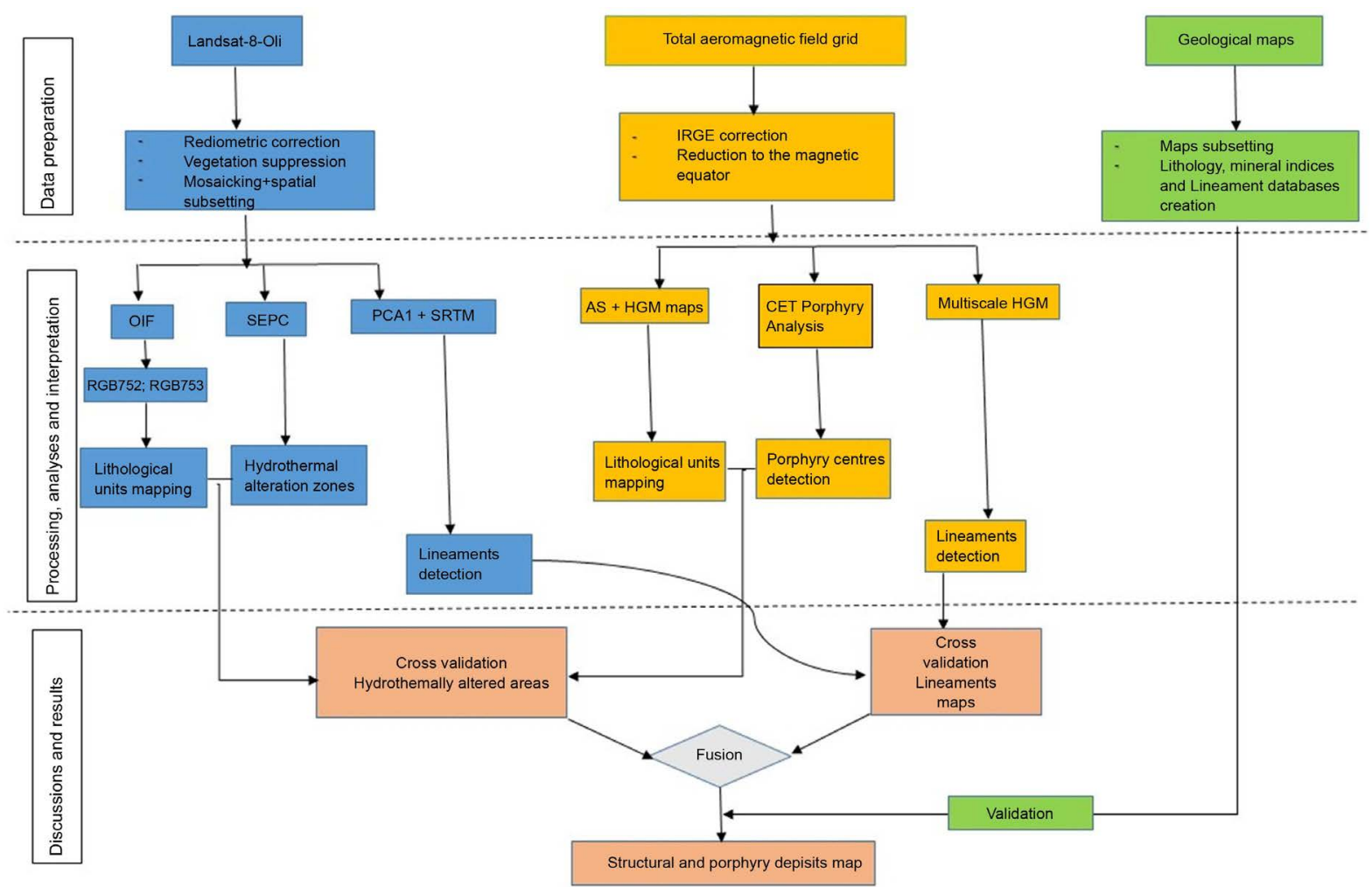

Figure 3. Flow chart summarising the methodology of work. 
lithology. The overall coloration is marked by dark tones showing that the lithology is made up of only metamorphic crystalline rocks. The FCC involving the bands 752; 753 in the RGB order (Figure 4) outline well the gneiss formations in the northern part of the study area as a yellow (Figure 4(a)) or a reddish (Figure 4(b)). These colours are due to high absorption of probably iron oxides, micas, feldspars and amphibole minerals in the SWIR bands. These minerals are dominant in gneisses. The gneiss rocks have a south boundary formed by a broad NE-SW line passing south of Yaounde and west of Akonolinga which seems to correspond to the gneiss/schists formations boundary in the Neoproterozoic domain.

The FCC maps (Figure 4) show south and east of gneisses as a mix of dark, dark reddish and dark blue tones with some greyish patchworks. The dark shades of blue may be characteristic to the presence of minerals such as calcite, muscovite, dark minerals, fine grains of pyrite and graphite. Reddish tones may be caused by the presence of ferric oxides, chlorite and amphiboles while the greyish tones throughout the entire map result from the reflection in all the
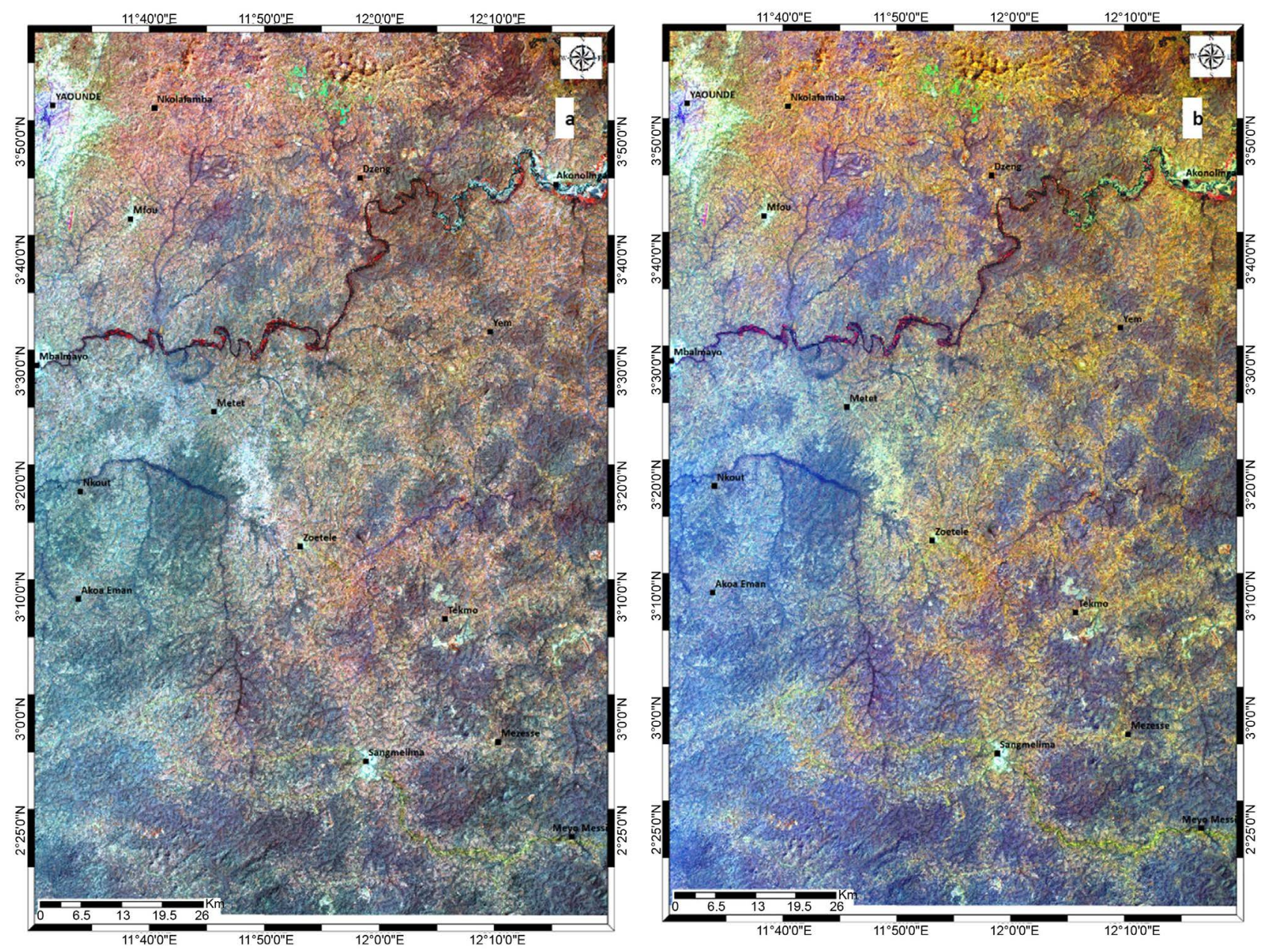

Figure 4. False colour composites (a) RGB752; (b) RGB753. The two images clearly outline the Panafrican gneisses (reddish) and schists (dark red) in the north of the study area. 
bands characterising quartz-rich minerals (quartzites). The candidate rocks here are quartz-muscovite schists, pyritic or graphitic schists and quartz-schists. In the schists region, the boundaries between the varieties of schists are diffuse because they are mixed. Thus, they probably form the same schists belt.

South of Nkout (Figure 4), discrimination of the Ntem complex rocks is not obvious. However, the Akoaeman zone, exhibits dark blue tones with patchwork of pale blue to cyan and pale greenish which probably correspond to tonalites. In the Sangmelima zone, the tones are pink to reddish due to high SWIR and medium to low reflectance in bands 5 and 2 or 3 of amphiboles, feldspars, micas, pyroxenes and olivine minerals. This suggests the existence of an igneous or meta-igneous complex, probably the granites/granodiorites and other mafic to ultramafic or subcrustal materials herein. These rocks are better evidenced by magnetic data.

\subsubsection{Aeromagnetic Qualitative Analyses}

Magnetic data (Figure 5) differentiate Panafrican terranes to the north from CC rocks to the south. The Panafrican domain appears as a quiet magnetic background (low HGM and AS values, Figure 4) with some anomaly peaks around

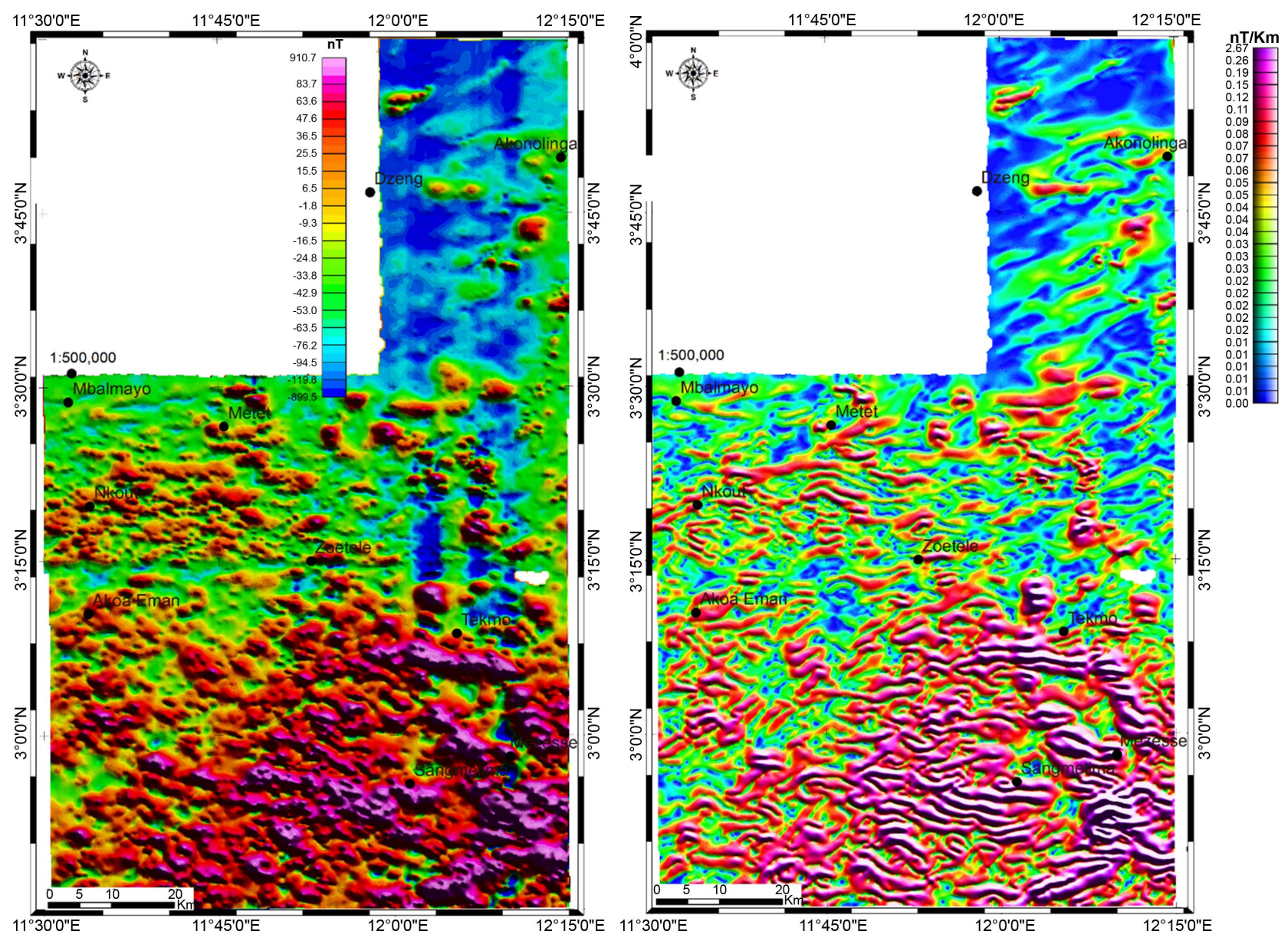

Figure 5. (a) Analytic signal and (b) Horizontal gradient magnitude maps. 
Akonolinga, around Metet, probably due to intrusions or deep faults or fractures affecting the Paleoproterozoic basement of the CAFB. Southward from Nkout, an area of HGM intermediate anomalies represents the Ntem complex TTGs, gneisses and other granitoids. The AS and HGM anomaly peaks surrounding Sangmelima (Figure 5) possibly charnockites and many other mafic to ultramafic or subcrustal contributions into the local rock budget recognised as greenstones belt relics. The TTG/Charnockites boundary is sub-circular east to north, and NE-SW, west of Sangmelima.

The refinement from the AS map reveals a sparse occurrence of intrusions in the CAFB (except at, and, east of Metet) whereas the Ntem complex has more intrusions (Figure 5(b)). The high number of sub-circular anomaly peaks interpreted as various age intrusions is a possible imprint of a hydrothermal activity which was high in charnockites, moderate in the TTG and low in the CAFB. Particularly, we interpret this poor occurrence of intrusions in the schists/TTG boundary as an evidence of a discrete influence of the Panafrican event on the CC.

\subsection{Lineaments Detection and Interpretation}

Quantitatively, the remotely sensed data analysis (Figure 6(a)) enabled to highlight more (863) lineaments than the aeromagnetics. These lineaments make a cumulative length of $3843.90 \mathrm{~km}$, for a minimum length of $0.56 \mathrm{~km}$, a maximum length of $21.73 \mathrm{~km}$ and a corresponding average length of $4.67 \mathrm{~km}$. Qualitatively, the major lineaments in the CAFB follow the WNW-ESE to NNW-SSE and NNE-SSW directions in gneisses; and the WNW-ESE and NNE-SSW to NE-SW, directions in schists. In the Ntem complex, the major lineaments are oriented NE-SW and NW-SE. These lineaments describe locally, contacts, faults, folds, dextral (e.g. Yaounde-Mfou area) or sinistral (e.g. Zoetele-Sangmelima) shear zones or strike-slips.

The aeromagnetic data analysis over the Yaounde-Sangmelima area evidenced various lineaments (Figure 6(b)). The main directions they follow are NE-SW to ENE-WSW, NW-SE to WNW-ESE and N-S. These probably correspond to folding traces, fracture, faults, dykes or geological contacts between major formations. The continuation of these lineaments clearly shows that some of them are faults affecting both the CAFB and the Ntem complex.

Together, remote sensing and magnetic lineaments (Figure 9) highlight the dominance of the NE-SW, NW-SE and N-S directions with some local variations (WNW-ESE, ENE-WSW, NNW-SSE and NNE-SSW). Putting aside all the secondary and minor lineaments, the major lineaments form throughout the whole Yaounde-Sangmelima region a broad NE-SW network of faults that affect the deep basement of both the Ntem complex and the Yaounde Group. Thus it would had formed before the emplacement of the Yaounde Group that it affected through post emplacement reactivations. These NE-SW lineaments intersect or are intersected by N-S and WNW-ESE to NW-SE lineaments which make 

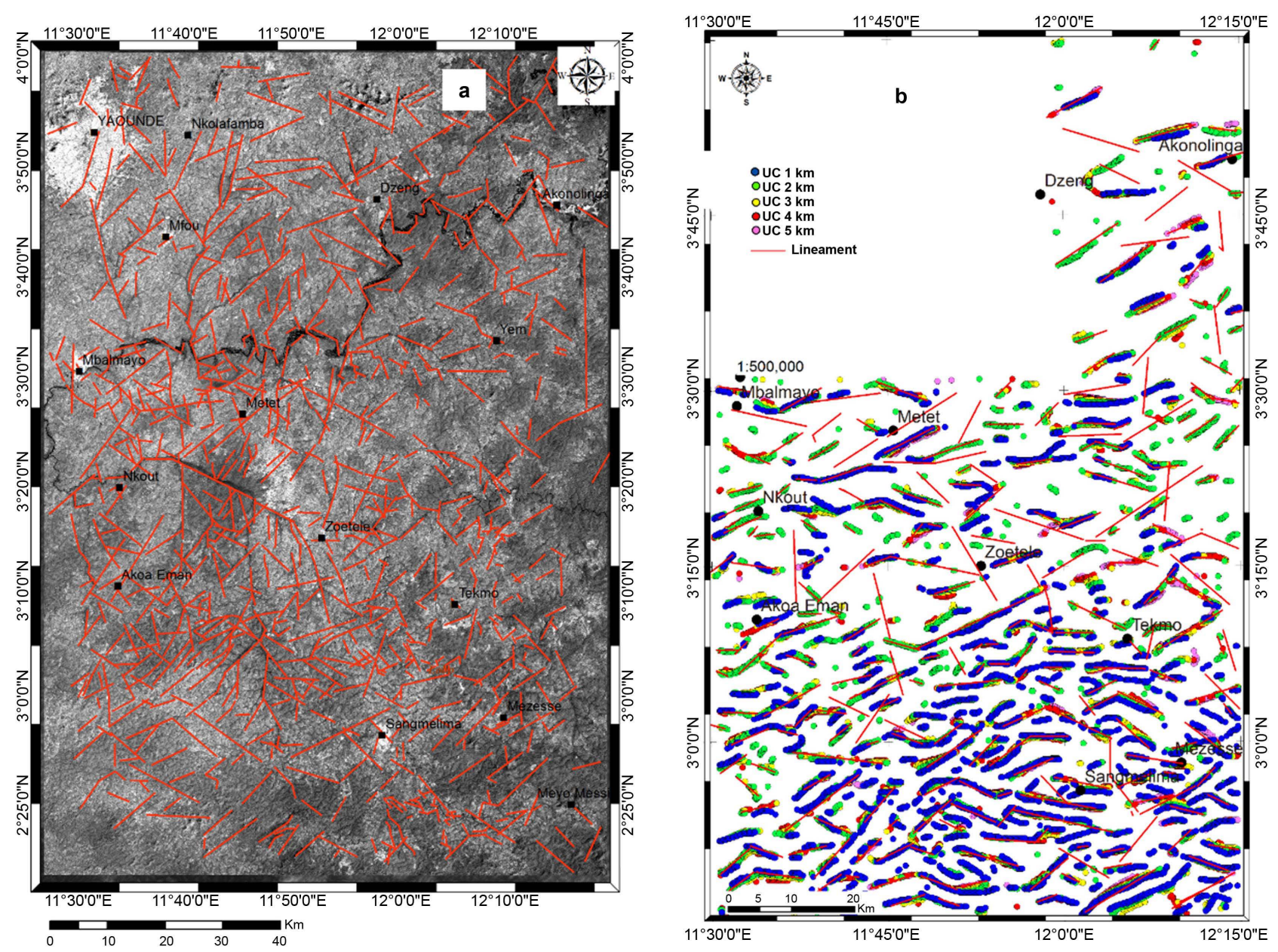

Figure 6. (a) Landsat 8 sensed lineaments; (b) Magnetic lineaments from HGM.

it interpretable as a major sinistral shear concupiscent to transpressional movements both the Ntem complex and the Yaounde Group. Moreover, there is a family of major WNW-ESE and E-W lineaments that form an E-W band between Mbalmayo and Tekmo that can be interpreted as the CAFB/CC southern limit, a faulty contact that represents the thrust line of the CAFB/CC along which visible WNW-ESE to NW-SE strike-slips of shear movements seems to have occurred.

In the $\mathrm{CAFB}$, the subparallel lineaments are relatively widely spaced, as a result of a gentle folding of gneisses and schists probably resulting from a less intense compression in the southern part of the CAFB. The folds and faults as well as other fractures and shear zones (e.g. the area is affected to the north by NE-SW dextral strike-slips-see Figure 6 and Figure 9) observed, suggest that the deformation conditions were ductile to brittle-ductile and the variability in their directions is an imprint of a multi staged and intense tectonics. Indeed, these lineaments in the CAFB result from the Gondwana amalgamation (Neoproterozoic) and breakup (Atlantic Ocean formation), and to the actual Somali Plate individualisation (East African Rift spreading) and the Africa/Eurasia Plates con- 
vergence tectonics.

In the Ntem complex, some lineaments are assumed to be Archaean, while other are may be related to:

1) The Eburnean event in Paleoproterozoic causing the development (or reactivation of pre-existing faults) of the SW-NE to WSW-ENE and WNW-ESE to NW-SE faults affecting both the Ntem complex and the Paleoproterozoic basement of the future Yaounde Group. These appeared as a response to pertaining compressional and extensional movements. This would lead to the development of strike-slips that would constitute the paleo senestrial SW-NE shear zone as revealed by this study in the Yaounde-Sangmelima area.

2) The rifting at the northern edge of the Congo Craton caused by the detachment of the Adamawa-Yade block that led to the development of the Yaounde basin. During that rifting the faults above may have acted as a transform faults system where the SW-NE to WSW-ENE faults are in the spreading direction. The WNW-ESE to NW-SE faults and fractures would line up with the rift axis and later become the southern CAFB/Congo Craton limit depicted by the set of WNW-ESE faults that form an E-W lineament around latitudes $\mathrm{N} 03^{\circ} 20^{\prime}$ and $\mathrm{N} 03^{\circ} 17^{\prime}$.

It is then evident that all the brittle structures outlined in the study area are either newly created or reactivated, depending on the stress and strain regimes upon the northern margin of the CC from Archaean to Cainozoic.

\subsection{Hydrothermal Alteration Zones Mapping}

\subsubsection{Feature Oriented PCs}

The application of the Crosta technique for the detection of clays and iron oxides anomalies led to Table 3. Clays are traced by the behaviour of the hydroxyl $(\mathrm{OH})$ group in the Clay band (SWIR region) where it has a high reflectance in the SWIR 1 and a strong absorption in SWIR2. Scrutinising the loading of each band for the four FPCs obtained for the OH (Table 3(a)), for PCOH4 band 6 contributes at -0.796 and band 7 loading is 0.532 , in line with the above comments. By inverting PCOH4, clayey zones will be observable as pale grey to white pixels in the southern part on the $\mathrm{PCOH} 4$ grey-scaled image (Figure 7(a)). In the north, alluvia in the Nyong River appear bright white in Akonolinga, whereas an anomalous clayey zone is visible west of Akonoloinga.

Regarding the detection of iron-rich minerals, in Table $3(\mathrm{~b}), \mathrm{PCFe} 4$ is characterised by a high loading from band 4 (0.658) related to a high reflectance and a very low contribution from band $2(-0.026)$ corresponding to a very strong absorption. This is characteristic to the presence of iron-rich minerals which generally have a very high reflectance in the red band and a strong absorption in the blue band. Therefore, iron oxide targets will appear as greyish to dark pixels on the grey-scaled image. But the PCFe4 is influenced by the high loading from band 3 (green) due to the dense canopy in the area what makes them almost no detectable (Figure 7(b)). 

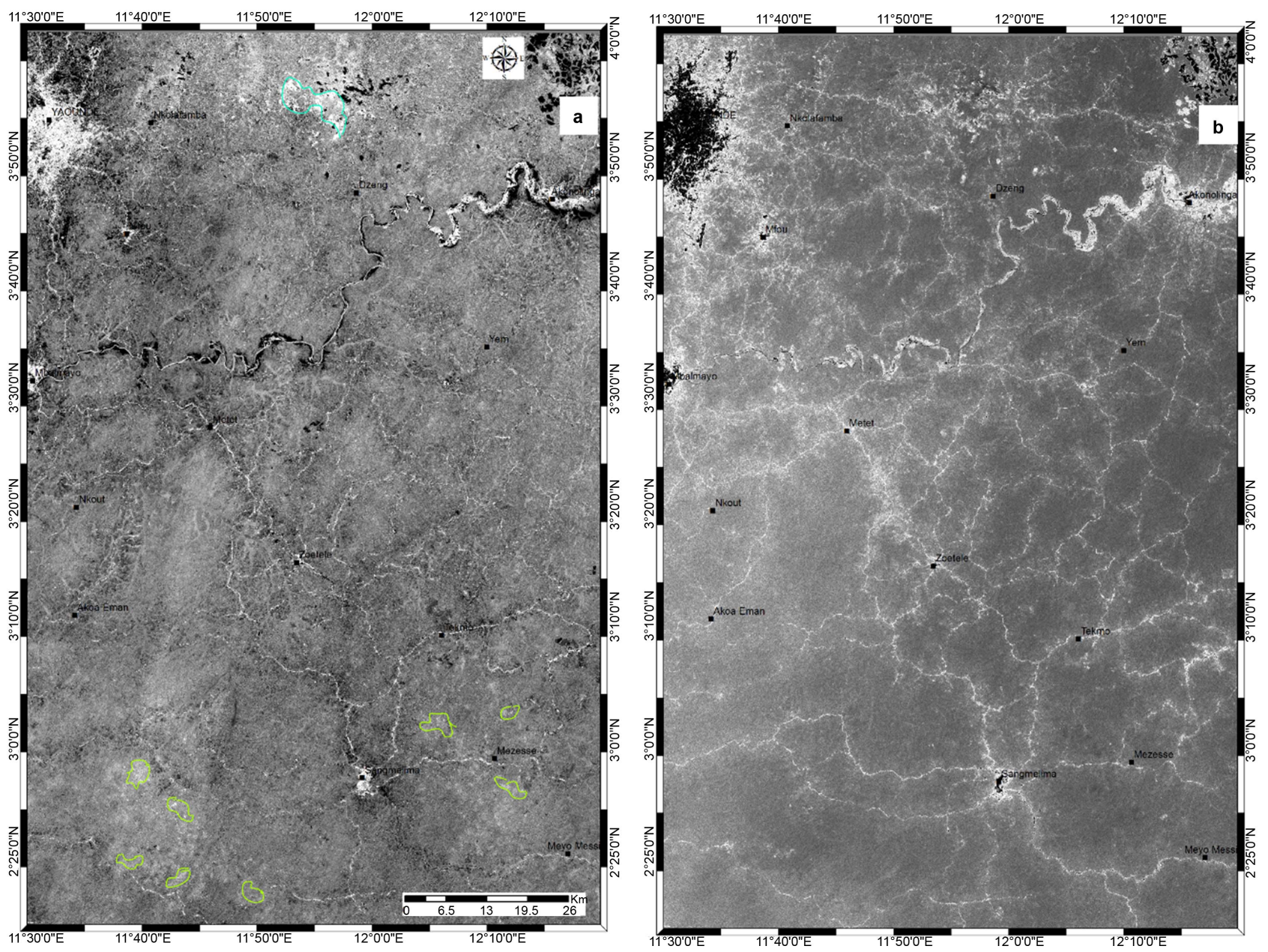

Figure 7. FPCS maps of the study area. (a) FPCOH1 and (b) FPCFe2 highlighting respectively, clays and iron oxides.

\subsubsection{Porphyry Centre Detection from Magnetic Data}

The application of the CET-porphyry detection tool on magnetic data led to the mapping of a total of 66 centres porphyry centres which correspond to intrusive bodies that occur in the study area (Figure 8 ). The straight visible point is that 61 of these centres are located in the Ntem complex and the remaining 5 centres (i.e. $7.58 \%$ of the gross total) are located in the Yaounde Group of the CAFB. Of the porphyry centres mapped in the CAFB domain, 3 centres are found in schists, in the vicinity of the schists/TTG boundary while the 2 other centres are located at this boundary. As a result, we interpret this very low occurrence of porphyry centres as an evidence of the absence of magmatic activity within the Yaounde Group in general, suggesting that no hydrothermal alteration of the Neoproterozoic rocks of the Yaounde and Mbalmayo series.

Contrasting with the CAFB domain, the Ntem complex records.92.42\% of the porphyry centres of the study area (Figure 8) but their variable distribution depends on the change in the nature or composition of its main rocks formations. Indeed, the results enable to distinguish an area of less dense occurrence of porphyry centres (21 centres) from an area of more densely populated (40) porphyry centres which corresponds to what is hitherto regarded as an intrusive 


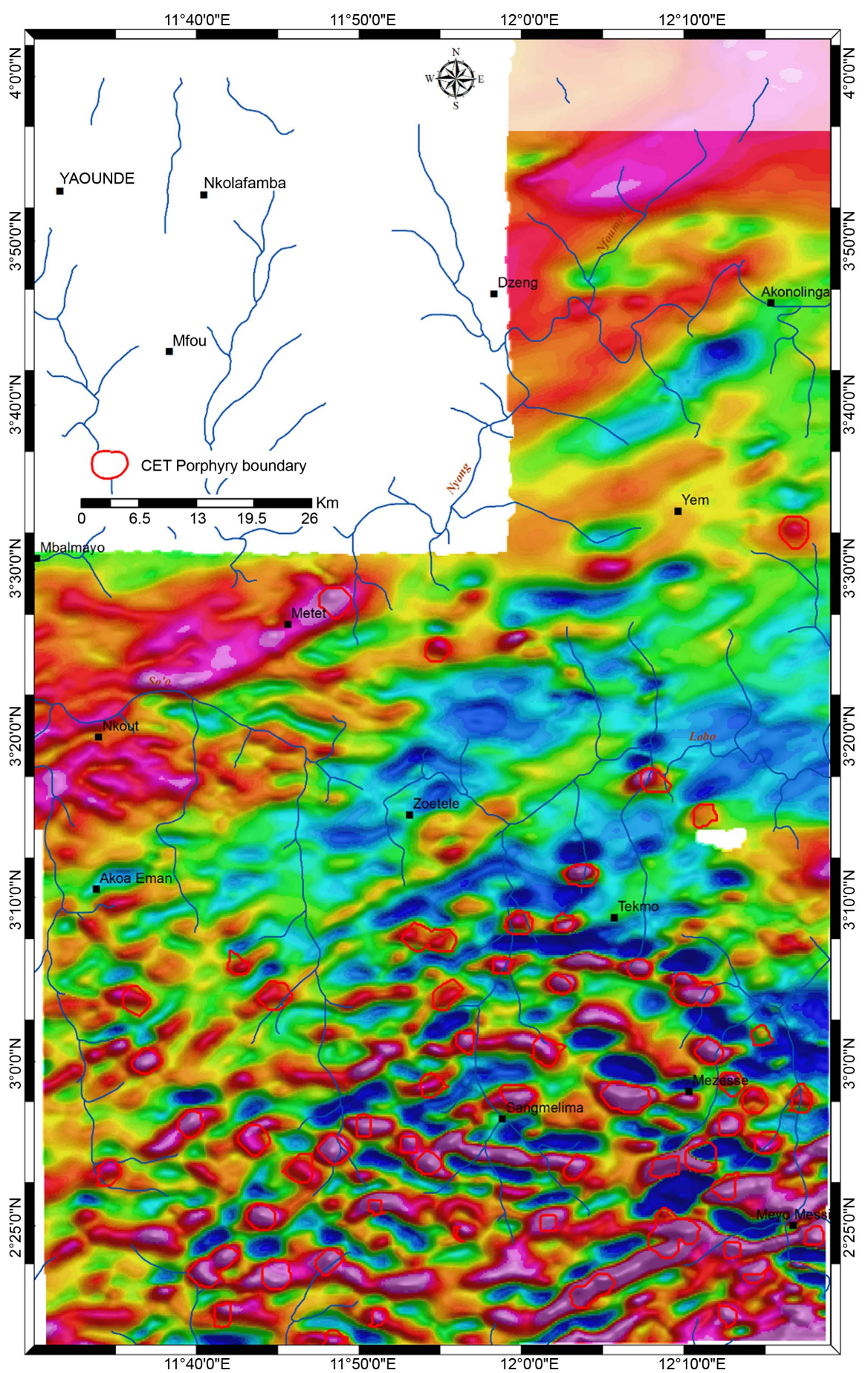

Figure 8. Porphyry domains overlain on the RTE map.

complex, in regards with its dramatically high porphyry centres percentage (60.60\% of the gross total). This intrusive complex merely corresponds to the charnockites, whereas the less densely populated area seemingly matches the intrusive TTG of the Ntem complex. This location of intrusive bodies within the TTG and charnockites complex shows that the Panafrican orogeny did not affect or slightly affected the Ntem complex. It can also show that no magmatic events 
occurred in the Ntem complex in relation with the Panafrican event but they are rather pre-Panafrican and possibly not tectono-metamorphic.

\section{Discussion}

\subsection{On Lithology Mapping}

The lithology mapping from remote sensing confirmed the metamorphic character of the basement lithology as they are generally visible in dark shades in the true colour composition. The reflectance signatures in the north of the study area (Figure 4(a); Figure 4(b)) has been interpreted as corresponding to a mixture of garnet, biotite, amphibole, quartz, kyanite, feldspar and chalcopyrite. These minerals are constituents of Panafrican gneisses of the Yaounde Group [42] [79] and various age gneisses worldwide. Besides, mix of dark reddish, dark blue, dark greenish and greyish tones in metamorphic rocks in general indicate the presence of muscovite, calcite, feldspars (orthoclase and albite), garnets, chlorite, quartz along with accessories minerals such as iron oxides, tourmaline or zircon [42] [44] [80] This has been globally interpreted as schists (quartz-muscovite schists, quartz-schists and muscovite schists) and quartzites in accordance with [42] [43] [65]. Moreover, the study was incapable of differentiating the Mbalmayo schists from the schists of the Yaounde series based on the spectral reflectance. This unquestioned differentiation to date, was recognised by pioneer studies (e.g. [43]) on the southern member unit of the CAFB which consider the Yaounde Group as made up of two distinct series: 1) the Yaounde series (gneisses + micaschists) and 2) the Mbalmayo schists. One probable reason of the inability of this study to clearly distinguish the schists of the Yaounde series from the Mbalmayo schists is that they may belong to the same unit, hence differences between them would account for simple variations observed in a same schists belt. Till date, only works by [44] are supportive of this point of view so, more geochemical studies in the schists formations of the Yaounde Group need to be carried out for clarifications.

The discrimination in between the Ntem complex rocks was not evident from the RS analysis (Figure 2(a); Figure 3(a); Figure 4(b)). In fact, their close mineralogical content provides them with almost the same signature, possibly because the rocks of the Ntem Complex derive from the same igneous protolith [47] [53]. Thus the igneous nature of these rocks favoured their mapping and differentiation through aeromagnetics. Indeed, the complementary use of aeromagnetic data permitted to segregate Tonalites TTG from an intrusive complex of granodiorites and granites centred on Sangmelima as well as greenstone relics documented from previous works (e.g. [43] and references therein). Moreover, from the HGM and the AS maps (Figure 5) and integrating the available geological information in the area [43], the study inferred, other greenstone relics south of Sangmelima in the intrusive complex. The same approach was used by [81] to highlight new greenstone relics northeast of those of the geological map. Highlighting another greenstone relic is a contribution in updating the reference geological map of southern Cameroon and it increases the mineral interest in the 
Ntem Complex.

\subsection{Structural Mapping and Geodynamic Evolution at the Northern Margin of the Congo Craton}

The study highlights in the Yaounde-Sangmelima region, many fractures and faults that affect both the Ntem Complex and the CAFB. The directions of the major structures are mainly SW-NE, WNW-ESE, NW-SE, SSW-NNE, WSW-ENE and N-S. The remote sensing results are consistent with magnetic results (Figure 9). These structures and directions are consistent with previous studies [25] [35] [82] [83] [84] [85] in the area and at the vicinities. Indeed, these works have highlighted many faults or fractures interpreted as tectonic accidents affecting the CC, the basement of the CAFB domain without providing a real explanation on the faulting history or kinematics to help understanding geodynamics at the northern margin of the CC.

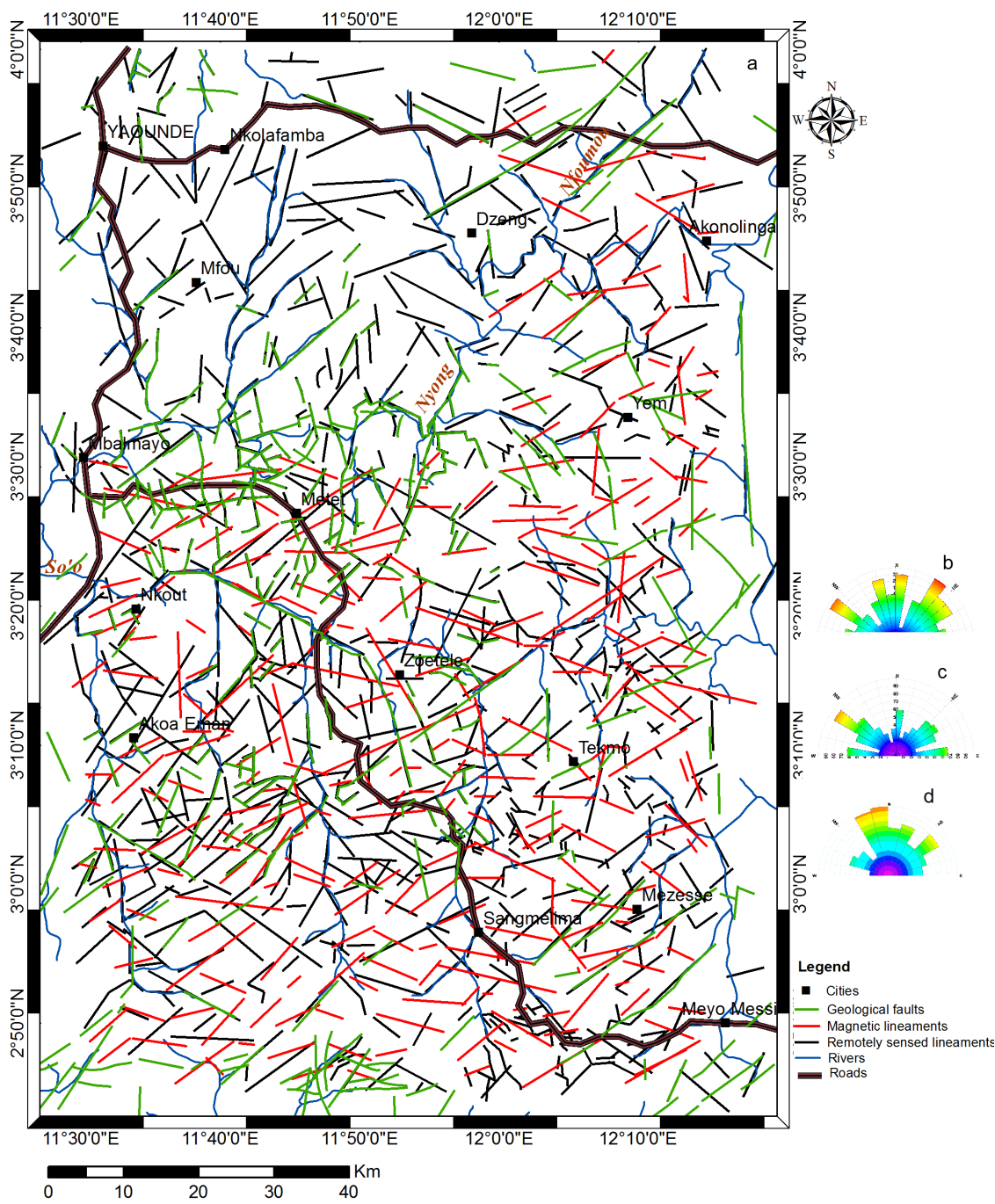

Figure 9. Lineaments map of the study area showing the correlation between previous geological (green lines), the magnetic (red lines) and the remotely sensed (black lines) lineaments. Respective rose diagrams (b, $c, d)$. 
This study proposes that the NE-SW to WSW-ENE major faults/fractures affecting both the Ntem complex and the CAFB are within a single paleo shear zone which have controlled deformations at the northern margin of the Congo Craton from the Archaean to the Precambrian and further in the Cenozoic. This confirms the idea recently suggested by [86] and correlates the shear zones highlighted by [82] in the Sangmelima area that we suggest it belongs to the network from this paper. The sinistral shear movements in the Ntem Complex are pre-Panafrican as suggested by the orientation of the greenstone relics (Figure 1). The weakening of the Ntem complex crust in response to resurgence of various tectonothermal events [53] [87] may have led to the setting of the NE-SW lineaments during the Eburnean orogeny and the maturation of the ESE-WNW to E-W faults affecting the paleo Proterozoic basement, that would later form a rift at the northern margin of the CC.

Rifting at the northern margin of the CC has been recognised by [65] and [86]. Therefore, the NE-SW to WSW-ENE fractures and faults affecting both the Ntem complex and the Paleoproterozoic basement of the CAFB to the north, would be the structures guiding the spreading direction of the Yaounde basin. Rifting and limited oceanisation was related with the late Paleoproterozoic to early Neoproterozoic detachment of the Adamawa-Yade block from the CC before the Panafrican orogeny [88]. So, the collapse of the basement evidenced by [85] [89] [90] under the Yaounde group are imprints of these extensional processes at the northern and southern margins of the Congo continent due to the circum-Congo subduction zone depicted by [91] in his reconstruction of the Rodinia supercontinent at ca $1000 \mathrm{Ma}$. Hence, the stress from the northern branch of the circum-Congo subduction zone would cause the opening of the Paleoproterozoic reworked crust at a weakened cratonic zone north of the CC, the metacratonised Ntem Complex [92], to form the Yaounde basin. The ESE-WNW to E-W faults south of Mbalmayo and north of Tekmo define a main E-W lineament corresponding to the southern CAFB/CC boundary (thrust line). The vertical to subvertical geometry of this faults [43] [66] [79] may have been acquired when they development during the rifting and probably remained unchanged thus inherited from the aforesaid rifting. In this case, that would justify the absence of Panafrican schists relics on top of the Ntem Complex (even at the vicinity of the CAFB/CC south boundary) as pointed by [42] [79]. Also, this geometry preservation raises the question on the involvement of the CC during the Panafrican orogeny at its northern margin.

Despite the need of more structural and petrophysical data at the vicinities of the $\mathrm{CAFB} / \mathrm{CC}$ south limit, this study considers the mentioned faults geometry to back up the assumption that the Ntem Complex and its foreland constituted a passive margin [61], hence the diffuse effects of the Panafrican tectonics onto the Ntem Complex reported by some geological works [79]. [49] observed mylonites in the TTGs south of Mbalmayo along the CAFB/CC boundary that we interpret as imprints of ESE-WNW transpressive movements along the Mbalmayo schists 
/CC contact line in response to late to post-Panafrican tectonics (Trans-Saharan orogeny) proving the importance of this tectonic feature. This importance as well as the geodynamic response of the CC and the Central Africa Rift System must be investigated by future works in regards with the ongoing stress related to the East African rifting and the NNE-SSW to NE-SW convergence of Africa towards Eurasia. Whatever, the multiplicity of the directions of the mapped faults shows how difficult it is to reconstruct the tectonic history of the northern margin of the CC.

The use of magnetic data permitted to highlights some intrusions mainly located in granitoids of the Ntem Complex (Figure 7) whereas almost no evidence of igneous activity is highlighted north in the CAFB domain. This spatial close relation of these intrusive bodies with granitoids presumed at the regional scale that there is no real Panafrican influence on the Ntem Complex rocks. [41] supposed that the Panafrican was not hot enough i.e. that the collision was weak at the margin of the Ntem Complex hence generating LP-LT metamorphic conditions which could only lead to the formation of low grade schists at the $\mathrm{CAFB} / \mathrm{CC}$ boundary in Neoproterozoic. In the CAFB, this may be the reason why intrusive bodies are very scarce or not reported in the Yaounde Group schists belt by many previous studies [43] [89] contrarily to the Poli schists in northern Cameroon (far away from the Ntem Complex) which recorded intense intrusive to extrusive activity in Neoproterozoic consistently with a real subduction mechanism, as documented therein by topic related studies [93] [94]. This was justified by some recent works with the existence of a micro plate or a micro continent north of the CC, probably the Adamawa/Yade microcontinent detached from the CC (see, e.g. [88] [95] [96], on this important issue); and validates effective but limited rifting processes at the northern margin of the CC supported by this study and [65]. We further assume that the LP-LT conditions hitherto evoked imply a non or limited reactivation of the Paleoproterozoic faults/fractures which disabled ascent of subcrustal materials.

Despite the lack of data, we propose that the closure of the Yaounde basin in late Neoproterozoic shall be understood as a result of simple compressions between a fixed CC and a moving Adamawa/Yada/East Sahara Block rather than a normal collision as seen worldwide [97] [98] [99] [100] [101]. Therefore, the development of the southern CAFB is a non-collisional orogeny and the consideration of a CC subducted below the CAFB is geodynamically misleading and should be avoided. However, these conclusions are matter of debate and transduce the complexity of the geological history of the northern margin of the CC in particular, as well as enigmas related to the Congo continent in the pre-Gondwana reconstructions. Notwithstanding the lithologic and tectonic links well demonstrated between South America and Africa [57] [102], reassessment of the timing of events could better enlighten the Neoproterozoic evolution of the transition zone at the northern margin of the CC. Another challenge not openly discussed in this work is to investigate the response of this 
transition zone to both the ongoing African plate geodynamics.

\subsection{Hydrothermal Alteration Mapping and Mining Implications}

Landsat 8 OLI data are generally efficient in mapping hydrothermal alteration zones which correspond to areas of clay minerals (with or without some iron oxides) accumulations [16] [19]. Contrarily to most presented studies (mainly carried in open canopy or semi-arid areas), they weakly mapped hydrothermal alteration zones in the study area. This incapability is probably due to the dense vegetation and the thick lateritic cover. In fact, the tropical vegetation produces a high evapotranspiration whose signal is sometimes difficult to remove on satellite data. In another side, Landsat 8 OLI data SWIR region is too broad (only two bands) to enable good mineral characterisation, comparatively to some sensors like ASTER which propose a better sampling in the same domain (five SWIR bands) resulting in a better characterisation of subsurface mineral contents.

However, aeromagnetics overcame that difficulty by mapping porphyry centres like some works [103]. Porphyritic deposits are associated to intrusive or extrusive activity, and require felsic to intermediate magma chamber and/or a cooling pluton; the inter-granular space along bedding planes and fractures in host rocks of enables percolation of hydrothermal fluids that will precipitate ore minerals then leads to the formation of hydrothermal deposits [2] [104] [105]. This is consistent with the close spatial relation between the highlighted porphyry centres and the granitoids and the TTG suites of the Ntem complex (Figure 10) in one hand; and in another, location of these mapped porphyry centres at (or close to) faults junctions, in between two subparallel faults or along faults, and at the TTG/granodiorites contact zone. Recalling this study highlighted a major pre-Panafrican NE-SW shear zones, with local NE-SW and NW-SE shear zones (e.g. Sangmelima area), it is clear that faulting played a major role by allowing hydrothermal and oxidising fluids circulations in the Archaean to Paleo/Mesoproterozoic evolution of the Ntem Complex.

Hydrothermal alteration in the Ntem complex has been recognised by recent works at the vicinities of the study area (in areas subject to advanced mineral exploration works) which also showed that hydrothermalism occurred in the Ntem Complex in a shallow seawater, probably in a subduction context [106] [107] [108] [109]. Porphyry as a subclass of hydrothermal deposits, is associated with one or various intrusions of felsic to intermediate rocks [4] [110] [111] as it is the case in this portion of the Ntem Complex made up of TTG granites, granodiorites [41] [47]. Also, some of the porphyry centres from this study coincide or are located in the close proximity of porphyry granites, intrusions and/or known mineral indices mapped by [42]. In the Ntem complex, the indices having $\mathrm{Fe}-\mathrm{Au}$ (Iron Oxides-Gold; IOG) affiliation are mainly found out of greenstones in TTG, granodiorites and granitoids; they tend to confirm the existence of porphyry and/or IOCG deposits, despite the absence of $\mathrm{Cu}$ index in the study area. [112] while confirming the $\mathrm{Cu}$ depletion in Akom II southwest of the study area, rather revealed a S, Ni, and Au-PGE enrichment. Regarding the geodynamical, 


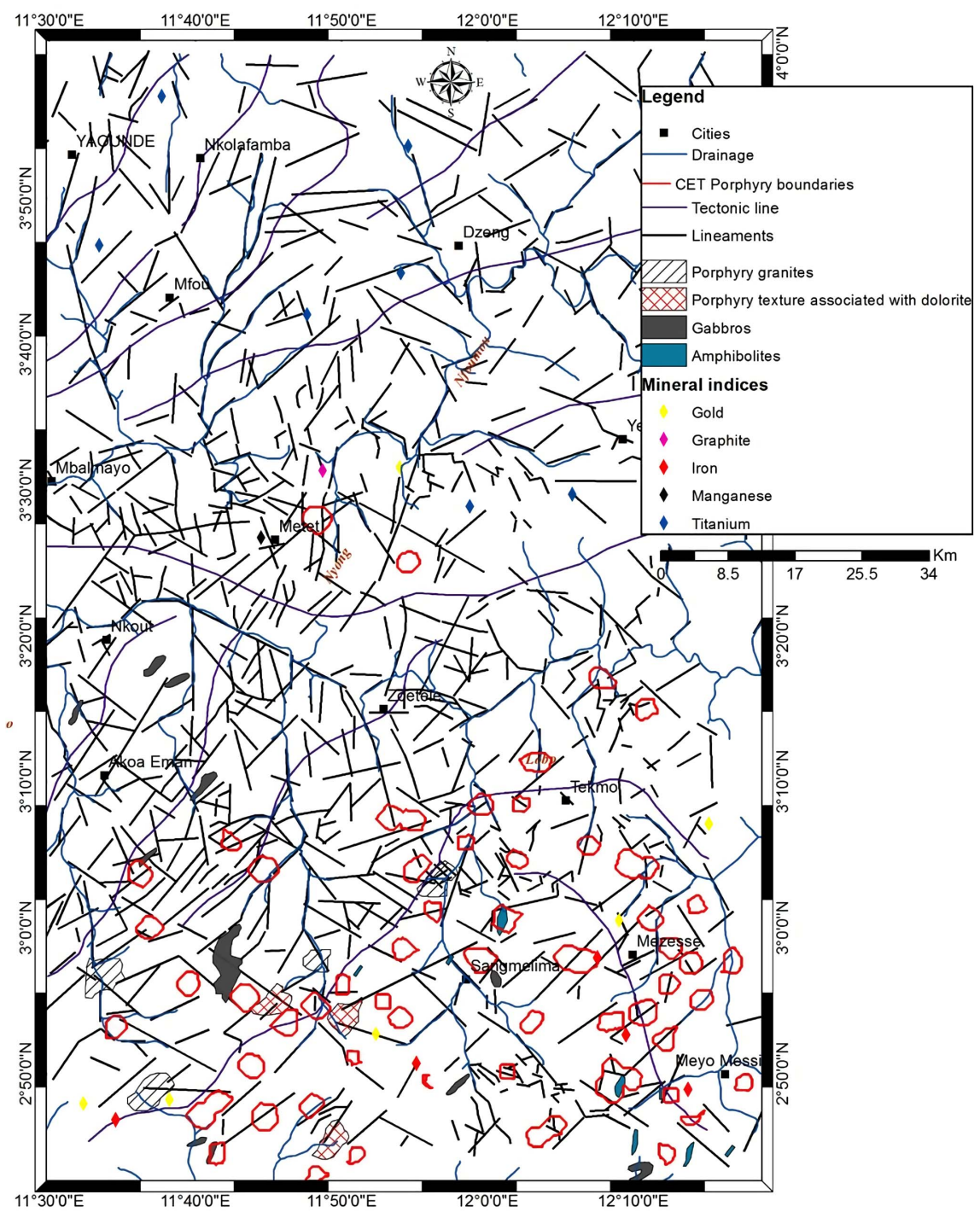

Figure 10. Correlation between highlighted porphyry domains and lineaments with exiting porphyritic textures and mineral indices.

lithological and structural context pertaining to this study area, hydrothermalism and absence of $\mathrm{Cu}$ would infer a Kiruma-type deposits [113]. However, [106] evidence of a $\mathrm{Ba}, \mathrm{Cu}, \mathrm{Zn}$ and $\mathrm{V}$ enriched iron oxide deposit suggests the existence of skarn or porphyry deposit nearly $45 \mathrm{~km}$ west of the study area (Binga project). Our results match with the existence of IOCG and porphyry/skarn ore deposits east and northeast Brazil [3] [4] [114]. Therefore, the Ntem complex in the transition zone at the northern margin of the CC potentially hosts many hydrothermal deposits which need to be explored.

\section{Conclusions}

An integrated analysis of Landsat 8, legacy aeromagnetic data and geologic maps was implemented as a predictive geological mapping approach in poorly exposed and inaccessible densely vegetated tropical region of southern Cameroon. The 
study objective was to revisit the structural and lithological knowledge of the northern margin of the Congo Craton in the Yaounde-Sangmelima area, with the resulting potential mining implications. The main results from the study are:

1) The faults and fractures outline a major SW-NE paleo strike-slips channel or shear zone affecting both the Ntem complex and the CAFB basement.

2) NE and NW trans tensional movements depicted by first and second order faulting, passageways for hydrothermal fluids.

3) Many mapped intrusions and porphyry centres structurally controlled by the regional and local shear zones as imprints of hydrothermal activity.

4) The close proximity of highlighted porphyry centres with mapped faults/fractures junctions, porphyry texture zones and mineral indices includes iron and gold suggest the presence of porphyry deposits in the Ntem complex.

5) Landsat 8 multispectral data are not good enough to predictively map hydrothermal alteration zones in poorly exposed, inaccessible and densely vegetated tropical area. High evapotranspiration from trees, thick lateritic cover, and the width of Landsat-8 SWIR bands may be the reason.

The results show that the mining potential of the Yaounde-Sangmelima in Ntem Complex should be positively reconsidered and more exploration activities shall be encouraged.

\section{Acknowledgements}

The authors are grateful to the anonymous reviewers whose remarks and comments will contribute in upgrading the current paper.

\section{Conflicts of Interest}

The authors declare no conflicts of interest regarding the publication of this paper.

\section{References}

[1] Naslund, H.R., Henríquez, F., Nyström, J.O., Vivallo, W. and Dobbs, F.M. (2002) Magmatic Iron Ores and Associated Mineralisation: Examples from the Chilean High Andes and Coastal Cordillera. Hydrothermal Iron Oxide Copper-Gold \& Related Deposits. A Global Perspective, 2, 207-226.

[2] Grooves, D.I., Condie, K.C., Goldfarb, R.J., Hronsky, J.M.A. and Vielreicher, R.M. (2005) Secular Changes in Global Tectonic Processes and Their Influence on the Temporal Distribution of Gold-Bearing Mineral Deposits. Economic Geology, 100, 203-224. https://doi.org/10.2113/gsecongeo.100.2.203

[3] Monteiro, L.V.S., et al. (2008) Spatial and Temporal Zoning of Hydrothermal Alteration and Mineralization in the Sossego Iron Oxide-Copper-Gold Deposit, Carajas Mineral Province, Brazil: Paragenesis and Stable Isotope Constraints. Miners Depo, 43, 129-159. https://doi.org/10.1007/s00126-006-0121-3

[4] Lobato, L.M., et al. (1998) Styles of Hydrothermal Alteration and Gold Mineralizations Associated with the Nova Lima Group of the Quadrilátero Ferrífero: Part I, Description of Selected Gold Deposits. Revista Brasileira de Geociências, 28, 339-354. https://doi.org/10.25249/0375-7536.1998339354 
[5] Zientek, M.L. (2012) Magmatic Ore Deposits in Layered Intrusions-Descriptive Model for Reef-Type PGE and Contact-Type Cu-Ni-PGE Deposits Magmatic Ore Deposits in Layered Intrusions-Descriptive Model for Reef-Type PGE and Contact-Type Cu-Ni-PGE Deposits. https://doi.org/10.3133/ofr20121010

[6] Richard, J.P. (2013) Giant ore Deposits Formed by Optimal Alignments and Combinations of Geological Processes. Nature Geoscience, 6, 911-916. https://doi.org/10.1038/ngeo1920

[7] Al Muntshry, A.N. (2011) Evaluating the Effectiveness of Multi-Spectral Remote Sensing Data for Lithological Mapping in Arid Regions: A Quantitative Approach with Examples from the Makkah Neoproterozoic Region, Saudi Arabia. Missouri University of Science and Technology, Rolla, MO.

[8] Liu, J.G. and Mason, P.J. (2009) Essential Image Processing and GIS for Remote Sensing. https://doi.org/10.1002/9781118687963

[9] Stewart, J.C. (2013) Developing Remote Sensing Methods for Bedrock Mapping of the Front Range Mountains, Colorado.

[10] Oruç, B. and Selim, H.H. (2011) Interpretation of Magnetic Data in the Sinop Area of Mid Black Sea, Turkey, Using Tilt Derivative, Euler Deconvolution and Discrete Wavelet Transform. Journal of Applied Geophysics, 74, 194-204. https://doi.org/10.1016/j.jappgeo.2011.05.007

[11] Ouattara, G., Gnammytchet, B. and Kouakou Yao, A. (2012) Contribution des images satellitales Landsat 7 ETM+ a la cartographie lithostructurale du Centre-Est de la Cote d' Ivoire (Afrique de l' Ouest ) to Cite This Version. International Journal of Innovation and Applied Studies, 1, 61-75.

[12] Kiran Raj, S. and Ahmed, S.A. (2014) Lineament Extraction from Southern Chitradurga Schist Belt Using Landsat TM, ASTERGDEM and Geomatics Techniques. International Journal of Computer Applications, 93, 12-20. https://doi.org/10.5120/16266-5993

[13] Mwaniki, M.W., Moeller, M.S. and Schellmann, G. (2015) A Comparison of Landsat 8 (OLI) and Landsat $7(\mathrm{ETM}+)$ in Mapping Geology and Visualising Lineaments: A Case Study of Central Region Kenya. International Archives of the Photogrammetry, Remote Sensing and Spatial Information Science, XL-7, 11-15. https://doi.org/10.5194/isprsarchives-XL-7-W3-897-2015

[14] Kayode, J.S., Nawawi, M.N.M., Khiruddin, B.A. and Khalil, A.E. (2016) Integrating Aeromagnetic and Landsat ${ }^{\mathrm{TM}} 8$ Data into Subsurface Structural Mapping of Precambrian Basement Complex. Journal of African Earth Sciences, 125, 202-213. https://doi.org/10.1016/j.jafrearsci.2016.11.010

[15] Crosta, A.P. and Rabelo, A. (1993) Assessing of Landsat TM for Hydrothermal ALteration Mapping in Central Western Brazil. Proceedings of Ninth Thematic Conference Geologic Remote Sensing Pasadinea, 3, 1053-1061.

[16] Amer, R., Kusky, T.M., Reinert, P.C. and Ghulam, A. (2006) Image Processing and Analysis Using Landsat ETM + Imagery for Lithological Mapping at Fawakhir, Central Eastern Desert of Egypt. ASPRS 2009 Annual Conference, Baltimore, MD, 9-13 March 2009.

[17] Safari, M., Pour, A.B., Maghsoudi A. and Hashim, M. (2013) Targeting Hydrothermal Alterations Utilizing Landsat-8 Andaster Data in Shahr-e-Babak, Iran. International Archives of the Photogrammetry, Remote Sensing and Spatial Information Sciences-ISPRS Archives, 42, 153-157. https://doi.org/10.5194/isprs-archives-XLII-4-W5-153-2017

[18] Pour, A.B. and Hashim M. (2015) Hydrothermal Alteration Mapping from Land- 
sat-8 Data, Sar Cheshmeh Copper Mining District, South-Eastern Islamic Republic of Iran. Journal of Taibah University for Science, 9, 155-166. https://doi.org/10.1016/j.jtusci.2014.11.008

[19] Labouré, C., Toledo, B. and De Assis L.M. (2016) Mapping Iron Oxides with Landsat-8/OLI and EO-1/Hyperion Imagery from the Serra Norte Iron Deposits in the Carajás Mineral Province, Brazil. Brazilian Journal of Geology, 46, 331-349. https://doi.org/10.1590/2317-4889201620160023

[20] Pramumijoyo, F.S. and Setijadji, L.D. (2018) Alteration Mineral Mapping to Identify Primary Tin Potential Using Landsat 8 Images and Geographic Information System in Rimba Kulit Area, Southern of Bangka Island. IOP Conference Series: Earth and Environmental Science, 212, Article ID: 012021. https://doi.org/10.1088/1755-1315/212/1/012021

[21] Akame, J.M., Mvondo Ondoa, J., Teikeu Assatse, W., Owona, S. and Olinga, J.B. (2014) Apport des images landsat-7 ETM+ a l'etude structurale du socle archeen de sangmelima ( SUD CAMEROUN ). Revue Francaise de Photogrammetrie et Teledetection, 206, 15-26.

[22] Teikeu, W., Njandjock, P., Tabod, C., Martial, J. and Nshagali, G. (2016) Hydrogeological Activity of Lineaments in Yaoundé Cameroon Region Using Remote Sensing and GIS Techniques. Egyptian Journal of Remote Sensing and Space Science, 19, 49-60.

[23] Didero, J., et al. (2016) Use of Landsat 7 ETM + Data for the Geological Structure Interpretation: Case Study of the Ngoura-Colomines Area, Eastern Cameroon. Journal of Geosciences and Geomatics, 4, 61-72.

[24] Mandeng, B., Bondje, L.M., Solange, A., Tchami, L. and Dieudonne, L.B. (2018) Lithologic and Structural Mapping of the Abiete-Toko Gold District in Southern Cameroon, Using Landsat 7 ETM+/SRTM. Comptes rendus Geoscience, 350, 130-140.

[25] Anaba Fotze, Q.M., Djieto Lordon, A., Penaye, J., Sep, J.P. and Neh Frun, M.I. (2019) Mapping Hydrothermal Alteration Targets from Landsat 8 OLI/TIRS and Magnetic Data Using Digital Image Processing Techniques in Garoua, North Cameroon. Journal of Geosciences and Geomatics, 7, 28-41.

https://doi.org/10.12691/jgg-7-1-4

[26] Nabighian, M.N., et al. (2005) The Historical Development of the Magnetic Method in Exploration. Geophysics, 70, 33-61. https://doi.org/10.1190/1.2133784

[27] Fairhead, J.D., Cooper, G.R.J. and Sander, S. (2017) Advances in Airborne Gravity and Magnetics. In: Proceedings of Exploration 17: Sixth Decennial International Conference on Mineral Exploration, 113-127.

[28] Keating, P. (1995) A Simple Technique to Identify Magnetic Anomalies Due to Kimberlite Pipes. Exploration and Mining Geology, 4, 121-125.

[29] Blakely, R.J. (1996) Potential Theory in Gravity and Magnetic Applications. Cambridge University Press, Cambridge. https://doi.org/10.1017/CBO9780511549816

[30] Reeves, C.V. (2005) Aeromagnetic Surveys-Principles, Practice \& Interpretation. Geosoft.

[31] Reid, A.B., Allsop, J.M., Granser, H., Millett, A.J. and Somerton, I.W. (1990) Magnetic Interpretation in Three Dimensions Using Euler Deconvolution. Geophysics, 55, 80-90. https://doi.org/10.1190/1.1442774

[32] Mushayandebvu, M.F., Lesur, V., Reid, A.B. and Fairhead, J.D. (2004) Grid Euler Deconvolution with Constraints for 2D Structures. Geophysics, 69, 489-496.

https://doi.org/10.1190/1.1707069 
[33] Prieto, C. (1996) Gravity/Magnetic Signatures of Various Geologic Models-An Exercise in Pattern Recognition. IGC Footnotes interpretation, 4, No. 4.

[34] Noutchogwe Tatchum, C., Koumetio, F. and Manguelle-Dicoum, E. (2010) Structural Features of South-Adamawa (Cameroon) Inferred from Magnetic Anomalies: Hydrogeological Implications. Comptes rendus Geoscience, 342, 467-474. https://doi.org/10.1016/j.crte.2010.03.004

[35] Feumoe, A.N., Ndougsa-Mbarga, T., Manguelle-Dicoum, E. and Fairhead, J.D. (2012) Delineation of Tectonic Lineaments Using Aeromagnetic Data for the South-East Cameroon Area. Geofizika, 29, 175-192.

[36] Som Mbang, M.C., Basseka, C.A., Kamguia, J., Etamè, J., Njiteu Tchoukeu, D.C. and Pemi Mouzong, M. (2018) Mapping of Deep Tectonic Structures of Central and Southern Cameroon by an Interpretation of Surface and Satellite Magnetic Data. International Journal of Geophysics, 2018, 1-11. https://doi.org/10.1016/j.crte.2010.03.004

[37] Haroni, H.A., Erren, H. and Westerhof, P. (2000) Integrated Analysis of Remote Sensing, Aeromagnetic, Geological and Mineral Occurrence Data for the Assessment of a Subduction Setting Along the Zagros Orogenic Belt of Iran 2 Geological Setting of Zagros Orogenic Belt. International Archives of the Photogrammetry, Remote Sensing, 33, 1700-1707.

[38] Opara, A.I., Onyekuru, S.O., Mbagwu, E.C., Emberga, T.T., Ijeomah, K.C. and Nwokocha, K.C. (2015) Integrating Landsat-ETM and Aeromagnetic Data for Enhanced Structural Interpretation over Naraguta Area, North-Central Nigeria. International Journal of Scientific and Engineering Research, 6, 186-195.

[39] Vicat, J. and Moloto-a-Kenguemba, G. (2001) Les granitoides de la couverture protérozoique de la bordure nord du craton du Congo (Sud-Est du Cameroun et Sud-Ouest de la République centrafricaine), témoins d'une activité magmatique panafricaine. Earth and Planetary Science Letters, 332, 235-242. https://doi.org/10.1016/S1251-8050(01)01521-X

[40] Tchameni, R., Mezger, K., Nsifa, N.E. and Pouclet, A. (2001) Crustal Origin of Early Proterozoic Syenites in the Congo Craton (Ntem Complex), South Cameroon. $\mathrm{Li}$ thos, 57, 23-42. https://doi.org/10.1016/S0024-4937(00)00072-4

[41] Li, X., Chen, Y., Li, J., Yang, C., Ling, X. and Tchouankoue, J.P. (2016) New Isotopic Constraints on Age and Origin of Mesoarchean Charnockite, Trondhjemite and Amphibolite in the Ntem Complex of NW Congo Craton, Southern Cameroon. Precambrian Research, 276, 14-23. https://doi.org/10.1016/j.precamres.2016.01.027

[42] Champetier de Ribes, G. and Aubague, M. (1956) Carte geologique de reconnaissance a l'echelle 1/500000. Notice explicative sur la feuille Yaounde-Est'.

[43] Maurizot, P., Abessolo, A., Feybesse, J., Johan, L. and Lecomte, P. (1986) Etude et prospection minière du Sud-Ouest du Cameroun. Synthèse des travaux de 1978 à 1985. Orleans, Cameroun.

[44] Nedelec, A., Nsifa, E.N. and Martin, H. (1990) Major and Trace Element Geochemistry of the Archaean Ntem Plutonic Complex South Cameroon): Petrogenesis and Crustal Evolution. Precambrian Research, 47, 35-50.

https://doi.org/10.1016/0301-9268(90)90029-P

[45] Shang, C.K., et al. (2004) TTG Magmatism in the Congo Craton; A View from Major and Trace Element Geochemistry, Rb-Sr and Sm-Nd Systematics: Case of the Sangmelima Region, Ntem Complex, Southern Cameroon. Journal of African Earth Sciences, 40, 61-79. https://doi.org/10.1016/j.jafrearsci.2004.07.005

[46] Shang, C.K., Siebel, W., Satir, M., Chen, F. and Mvondo Ondoua, J. (2004) Zircon 
$\mathrm{Pb}-\mathrm{Pb}$ and $\mathrm{U}-\mathrm{Pb}$ Systematics of TTG Rocks in the Congo Craton: Constraints on Crust Formation, Magmatism and Pan-African Lead Loss. Bulletin of Geosciences, 79, 205-219.

[47] Shang, C.K., Liégeois, J.P., Satir, M., Frisch, W. and Nsifa, E.N. (2010) Late Archaean High-K Granite Geochronology of the Northern Metacratonic Margin of the Archaean Congo Craton, Southern Cameroon: Evidence for Pb-Loss Due to Non-Metamorphic Causes. Gondwana Research, 18, 337-355. https://doi.org/10.1016/j.gr.2010.02.008

[48] Houketchang Bouyo, M., Penaye, J., Mouri, H. and Toteu, S.F. (2019) Eclogite Facies Metabasites from the Paleoproterozoic Nyong Group, SW Cameroon: Mineralogical Evidence and Implications for a High-Pressure Metamorphism Related to a Subduction Zone at the NW Margin of the Archean Congo Craton. Journal of African Earth Sciences, 149, 215-234. https://doi.org/10.1016/j.jafrearsci.2018.08.010

[49] Nedelec, A., Macaudiere, J., Nzenti, J.P. and Barbey, P. (1986) Évolution structurale et métamorphique des schistes de Mbalmayo (Cameroun). Implications pour la structure de la zone mobile panafricaine d'Afrique centrale au contact du craton du Congo. Comptes rendus de 1 Académie des Sciences Paris, 303, 75-80.

[50] Nzenti, J.P., Barbey, P., Macaudière, J. and Soba, D. (1988) Origin and Evolution of the Late Precambrian High, Grade Yaoundé Gneisses Cameroon. Precambrian Research, 38, 91-109. https://doi.org/10.1016/0301-9268(88)90086-1

[51] Ganwa, A.A., et al. (2008) Zircon207Pb/206Pb Evaporation Ages of Panafrican Metasedimentary Rocks in the Kombé-II Area (Bafia Group, Cameroon): Constraints on Protolith Age and Provenance. Journal of African Earth Sciences, 51, 77-88. https://doi.org/10.1016/j.jafrearsci.2007.12.003

[52] Feybesse, J.L., Johan, V., Maurizot, P. and Abessolo, A. (1987) Evolution tectonométamorphique libérienne et eburnéenne de la partie NW du craton zairois (SW Cameroun). In: Matheis, G. and Balkema, S.H., Eds., Current Research in African Earth Sciences, Rotterdam, 9-13.

[53] Tchameni, R., et al. (2010) Mineralogical Constraint for Metamorphic Conditions in a Shear Zone Affecting the Archean Ngoulemakong Tonalite, Congo Craton (Southern Cameroon) and Retentivity of U-Pb SHRIMP Zircon Dates. Journal of African Earth Sciences, 58, 67-80. https://doi.org/10.1016/j.jafrearsci.2010.01.009

[54] Castaing, C., Feybesse, J.L., Thieblemont, D., Triboulet, C. and Chèvremont, P. (1994) Paleogeographical Reconstructions of the Pan-African/Brasiliano Orogen: Closure of an Oceanic Domain or Intracontinental Convergence between Major Blocks? Precambrian Research, 67, 327-344. https://doi.org/10.1016/0301-9268(94)90095-7

[55] Toteu, S.F., van Schmus, W.R., Penaye, J. and Nyobe, J.B. (1994) U-Pb and Sm-Nd Evidence for Eburnian and Pan-African High-Grade Metamorphism in Cratonic Rocks of Southern Cameroon. Precambrian Research, 67, 321-347. https://doi.org/10.1016/0301-9268(94)90014-0

[56] Toteu, S.F., Van Schmus, W.R. and Penaye, J. (2006) The Precambrian of Central Africa: Summary and Perspectives. Journal of African Earth Sciences, 44, 7. https://doi.org/10.1016/j.jafrearsci.2005.12.002

[57] van Schmus, W.R., Oliveira, E.P., da Silva Filho, A.F., Toteu, S.F., Penaye, J. and Guimarães, I.P. (2008) Proterozoic Links between the Borborema Province, NE Brazil and the Central African Fold Belt. Geological Society, London, Special Publications, 294, 69-99. https://doi.org/10.1144/SP294.5

[58] Fernandez-Alonso, M., Tack, L., Tahon, A. and De Waele, B. (2010) The Protero- 
zoic History of the Proto-Congo Craton of Central Africa.

[59] Loose, D. and Schenk, V. (2018) 2.09 Ga Old Eclogites in the Eburnian-Transamazonian Orogen of Southern Cameroon: Significance for Palaeoproterozoic Plate Tectonics. Precambrian Research, 304, 1-11. https://doi.org/10.1016/j.precamres.2017.10.018

[60] Toteu, S.F., Penaye, J. and Djomani, Y.P. (2004) Geodynamic Evolution of the Pan-African Belt in Central Africa with Special Reference Geodynamic Evolution of the Pan-African Belt in Central Africa with Special Reference to Cameroon 1. Canadian Journal of Earth Sciences, 41, 73-85. https://doi.org/10.1139/e03-079

[61] Ngako, V. and Njonfang, E. (2011) Plates Amalgamation and Plate Destruction, the Western Gondwana History. In: Closson, D., Ed., Tectonics, InTech, London, 1-36.

[62] Mvondo, H., Owona, S., Ondoa, J.M. and Essono, J. (2007) Tectonic Evolution of the Yaounde Segment of the Neoproterozoic Central African Orogenic Belt in Southern Cameroon. Canadian Journal of Earth Sciences, 44, 433-444. https://doi.org/10.1139/e06-107

[63] Olinga, J.B., Mpesse, J.E., Minyem, D., Ngako, V., Ndougsa-Mbarga, T. and Ekodeck, G.E. (2010) The Awaé-Ayos Strike-Slip Shear Zones (Southern Cameroon): Geometry, Kinematics and Significance in the Late Pan-African Tectonics. Neues Jahrbuch für Geologie und Paläontologie, 257, 1-11. https://doi.org/10.1127/0077-7749/2010/0042

[64] Mvondo-Ondoa, J., Mvondo, H. and Den Brok, B. (2009) Pan-African Tectonics in Northwestern Cameroon: Implication for the History of Western Gondwana. Gondwana Research, 16, 163-164. https://doi.org/10.1016/j.gr.2008.12.006

[65] Nkoumbou, C., Barbey, P., Yonta-Ngouné, C., Paquette, J.L. and Villiéras, F. (2014) Pre-Collisional Geodynamic Context of the Southern Margin of the Pan-African Fold Belt in Cameroon. Journal of African Earth Sciences, 99, 245-260. https://doi.org/10.1016/j.jafrearsci.2013.10.002

[66] Manguelle Dicoum, E., Bokosah, A.S. and Kwende Mbanwi, T.E. (1992) Geophysical Evidence for a Major Precambrian Schist-Granite Boundary in Southern Cameroon. Tectonophysics, 205, 437-446. https://doi.org/10.1016/j.jafrearsci.2013.10.002

[67] Ndougsa-Mbarga, T., Layu, D.Y., Yene-Atangana, J.Q. and Tabod, C.T. (2014) Delineation of the Northern Limit of the Congo Craton Based on Spectral Analysis and 2.5D Modeling of Aeromagnetic Data in the Akonolinga-Mbama area, Cameroon. Geofísica Internacional, 53, 5-16. https://doi.org/10.1016/S0016-7169(14)71486-2

[68] USGS (2016) Landsat 8 (L8) Data Users Handbook.

[69] Chavez, P.S.J., Berlin, G.L. and Sowers, L. (1982) Statistical Method for Selecting Landsat MSS Ratios. Journal of Applied Photographic Engineering, 8, 23-30.

[70] Crosta, A.P. and Moore, J.M. (1989) Enhancement of Landsat Thematic Mapper Imagery for Residual Soil Mapping in SW Minas Gerais State, Brazil: A Prospecting Case History in Greenstone Belt Terrain. Proceedings of the 7 th Thematic Conference on Remote Sensing for Exploration Geology, 2-6 October 1989, 1173-1187.

[71] Nabighian, M.N. (1972) The Analytic Signal of Two-Dimensional Magnetic Bodies with Polygonal Cross-Section: Its Properties and Use for Automated Anomaly Inter-Pretation. Geophysics, 37, 507-517. https://doi.org/10.1190/1.1440276

[72] Roest, W.R., Verhoef, J. and Pilkington, M. (1992) Magnetic Interpretation Using the 3-D Analytic Signal. Geophysics, 57, 116-125. https://doi.org/10.1190/1.1443174

[73] Boyd, D.M. and Isles, D.J. (2007) Geological Interpretation of Airborne Magnetic Surveys-40 Years on. Proceedings of Exploration 07: Fifth Decennial International Conference on Mineral Exploration, Toronto, 9-12 September 2007, 491-505. 
[74] Archibald, N., Gow, P. and Boschetti, F. (1999) Multiscale Edge Analysis of Potential Field Data. Exploration Geophysics, 30, 38-44. https://doi.org/10.1071/EG999038

[75] Owona-Angue, M.L., Tabod, C.T., Nguiya, S., Kenfack, J.V. and Tokam Kamga, A.P. (2013) Delineation of Lineaments in South Cameroon (Central Africa ) Using Gravity Data. Open Journal of Geology, 3, 331-339. https://doi.org/10.4236/ojg.2013.35038

[76] Kue Petou, M.R., Owona Angue, M.L., Nfor, N., Ndougsa-Mbarga, T. and Manguelle-Dicoum, E. (2017) Determination of Structural and Geometrical Parameters of the Kribi-Campo Sedimentary Sub-Basin Using Gravity Data. International Journal of Geophysics, 8, 1210-1224. https://doi.org/10.4236/ijg.2017.89069

[77] Holden, E., Fu, S.C., Kovesi, P., Dentith, M.C., Bourne, B. and Hope, M. (2011) Automated Identification of Magnetic Responses from Porphyry Systems. Journal of Applied Geophysics, 74, 255-262. https://doi.org/10.1016/j.jappgeo.2011.06.016

[78] Nzenti, J.P., Barbey, P., Jegouzo, P. and Moreau, C. (1984) Un nouvel exemple de ceinture granulitique dans une chaîne protérozoïque de collision: Les migmatites de Yaoundé au Cameroun. Comptes Rendus de PAcadémie des Sciences Paris, 299, 1197-1199.

[79] Nedelec, A., Nzenti, J.P. and Barbey, P. (1986) Structural and Metamorphic Evolution of the Mbalmayo Schists (Cameroon). Implications for the Structure of the Pan-African Mobile Belt of Central Africa, Close to the Congo Crat. Comptes Rendus de I Académie des Sciences, 303, No. 2015.

[80] Shang, C.K., Muharrem, S., Nsifa Nkonguin, E., Liegeois, J.-P., Siebel, W. and Taubald, H. (2007) Archaean High-K Granitoids Produced by Remelting of Earlier Tonalite-Trondhjemite-Granodiorite (TTG) in the Sangmelima Region of the Ntem Complex of the Congo Craton, Southern Cameroon. International Journal of Earth Sciences, 96, 817-841. https://doi.org/10.1007/s00531-006-0141-3

[81] Li, X.-H., Chen, Y., Li, J., Yang, C., Ling, X.-X. and Tchouankoue, J.P. (2016) New Isotopic Constraints on Age and Origin of Mesoarchean Charnockite, Trondhjemite and Amphibolite in the Ntem Complex of NW Congo Craton, Southern Cameroon. Precambrian Research, 276, 14-23.

[82] Akame, J.M., et al. (2019) The Sangmelima Granite-Greenstone Belts (South Cameroon): Integration of Remote Sensing and Aeromagnetic Data for Structural Interpretation. The Egyptian Journal of Remote Sensing and Space Sciences, 22, 37-47.

[83] Tadjou, J.M., Njingti-Nfor, Kamguia, J. and Manguelle-Dicoum, E. (2008) Geophysical Prospecting of the Transition Zone between the Congo Craton and the Panafrican Belt in Cameroon. Earth Sciences Research Journal, 12, 169-180.

[84] Meying, A., Ndougsa-Mbarga, T. and Manguelle-Dicoum, E. (2009) Evidence of Fractures from the Image of the Subsurface in the Akonolinga-Ayos Area (Cameroon) by Combining the Classical and the Bostick Approaches in the Interpretation of Audio-Magnetotelluric Data. Journal of Geology and Mining Research, 1, 159-171.

[85] Shandini, N.Y., Tadjou, J.M. and Basseka, C.A. (2011) Delineating Deep Basement Faults in South Cameroon Area. World Applied Sciences Journal, 14, 611-615.

[86] Assembe, S.P., Ndougsa-Mbarga, T., Meying, A., Gouet, D.H., Ngoh, J.D. and Mono, J.A. (2019) Contribution of Geophysics to the Understanding of the Geodynamic Activity at the Northern Margin of the Congo Craton: A Case Study from Aeromagnetic Data Interpretation Over the Metet-Zoetele Region (Southern Ca- 
meroon). European Journal of Scientific Research, 152, 286-303.

[87] Takam, T., Makoto, A., Kokonyangi, J., Dunkley, D.J. and Nsifa Nkonguin, E. (2009) Paleoarchaean Charnockite in the Ntem Complex, Congo Craton, Cameroon: Insights from SHRIMP Zircon U-Pb Ages. Journal of Mineralogical and Petrological Sciences, 104, 1-11. https://doi.org/10.2465/jmps.080624

[88] Tchakounte Numbem, J., et al. (2018) Reply to Comment by Ngako and Njonfang on "The Adamawa-Yade Domain, a Piece of Archaean Crust in the Neoproterozoic Central African Orogenic Belt (Bafia Area, Cameroon)”, by Jacqueline Tchakounté et al., Precambrian Research 299 (2017) 210-229. Precambrian Research, 305, 516-518. https://doi.org/10.1016/j.precamres.2017.12.035

[89] Shandini, Y.N., Tadjou, J.M., Tabod, C.T. and Fairhead, J.D. (2010) Gravity Data Interpretation in the Northern Edge of the Congo Craton, South-Cameroon. Anuário do Instituto de Geociências, 33, 73-82.

[90] Basseka, C.A., Shandini, Y. and Tadjou, J.M. (2011) Subsurface Structural Mapping Using Gravity Data of the Northern Edge of the Congo Craton, South Cameroon. Geofizika, 28, 229-245.

[91] Scotese, C.R. (2009) Late Proterozoic Plate Tectonics and Palaeogeography: A Tale of Two Supercontinents, Rodinia and Pannotia. In: Craig, J., Thurow, J., Thusu, B., Whitham, A. and Abutarruma, Y., Eds., Global Neoproterozoic Petroleum Systems: The Emerging Potential in North Africa, 67-83. https://doi.org/10.1144/SP326.4

[92] Goussi, J.F., Bisso, D., Abdelsalam, M.G., Atekwana, E.A., Katumwehe, A.B. and Ekodeck, G.E. (2017) Geophysical Imaging of Metacratonizaton in the Northern Edge of the Congo Craton in Cameroon. Journal of African Earth Sciences, 129, 94-107. https://doi.org/10.1016/j.jafrearsci.2016.12.010

[93] Toteu, S.F. (1990) Geochemical Characterization of the Main Petrographical and Structural Units of Northern Cameroon: Implications for Pan-African Evolution. Journal of African Earth Sciences, 10, 615-624. https://doi.org/10.1016/0899-5362(90)90028-D

[94] Toteu, S.F., Van Schmus, W.R., Penaye, J. and Michard, A. (2001) New U-Pb and Sm-Nd Data from North-Central Cameroon and Its Bearing on the Pre-Pan African History of Central Africa. Precambrian Research, 108, 45-73. https://doi.org/10.1016/S0301-9268(00)00149-2

[95] Tchameni, R., Pouclet, A., Penaye, J., Ganwa, A.A. and Toteu, S.F. (2006) Petrography and Geochemistry of the Ngaoundere Granitoids in Central North Cameroon: Implications for Their Sources and Geological Setting. Journal of African Earth Sciences, 44, 511-529. https://doi.org/10.1016/j.jafrearsci.2005.11.017

[96] Ganwa, A.A., Siebell, W., Shang, K.C., Seguem, N. and Ekodeck, G.E. (2011) New Constraints from $\mathrm{Pb}$-Evaporation Zircon Ages of the Meiganga Amphibole-Biotite Gneiss, Central Cameroon, on Proterozoic Crustal Evolution. International Journal of Geosciences, 2, 138-147. https://doi.org/10.4236/ijg.2011.22014

[97] Han, T. and Nelson, J. (2015) Mapping Hydrothermally Altered Rocks with Landsat 8 Imagery: A Case Study in the KSM and Snow Field Zones, Northwestern British Columbia. Geological Fieldwork 2014, British Columbia Ministry of Energy and Mines, 103-112.

[98] Timm, J. (2001) Subduction and Continental Collision in the Lufilian Arc-Zambesi Belt Orogen: A Petrological, Geochemical and Geochronological Study of Eclogites and Whiteschists (Zambia). University of Kiel, Kiel.

[99] Kröner, A. and Stern, R.J. (2004) Pan-African Orogeny. Encyclopedia of Geology, 1, 
1-12. https://doi.org/10.1016/B0-12-369396-9/00431-7

[100] Zhao, Z., Zheng, Y., Zhang, J., Dai, L., Li, Q. and Liu, X. (2012) Syn-Exhumation Magmatism during Continental Collision: Evidence from Alkaline Intrusives of Triassic Age in the Sulu Orogen. Chemical Geology, 328, 70-88. https://doi.org/10.1016/j.chemgeo.2011.11.002

[101] Bouyo Houketchang, M., Zhao, Y., Penaye, J., Zhang, S.H. and Njel, U.O. (2015) Neoproterozoic Subduction-Related Metavolcanic and Metasedimentary Rocks from the Rey Bouba Greenstone Belt of North-Central Cameroon in the Central African Fold Belt: New Insights into a Continental Arc Geodynamic Setting. Precambrian Research, 261, 40-53. https://doi.org/10.1016/j.precamres.2015.01.012

[102] de Wit, M.J., Stankiewicz, J. and Reeves, C. (2008) Restoring Pan-African-Brasiliano Connections: More Gondwana Control, Less Trans-Atlantic Corruption. The Geological Society of London-Special Publications, 294, 399-412. https://doi.org/10.1144/SP294.20

[103] Elkhateeb, S.O. and Abdellatif, M.A.G. (2018) Delineation Potential Gold Mineralization Zones in a Part of Central Eastern Desert, Egypt Using Airborne Magnetic and Radiometric Data. NRIAG Journal of Astronomy and Geophysics, 7, 361-376. https://doi.org/10.1016/j.nrjag.2018.05.010

[104] Boadi, B., Wemegah, D.D. and Preko, K. (2013) Geological and Structural Interpretation of the Konongo Area of the Ashanti Gold Belt of Ghana from Aero-Magnetic and Radiometric Data. International Research Journal of Geology and Mining, 3, 124-135.

[105] Ganno, S., et al. (2017) A Mixed Seawater and Hydrothermal Origin of Superior-Type Banded Iron Formation (BIF)-Hosted Kouambo Iron Deposit, Palaeoproterozoic Nyong Series, Southwestern Cameroon: Constraints from Petrography and Geochemistry. Ore Geology Reviews, 80, 860-875.

https://doi.org/10.1016/j.oregeorev.2016.08.021

[106] Ngoran, G.N., Suh, C.E., Bowker, D., Verla, R.B. and Bafon, G.T. (2016) Petrochemistry of Two Magnetite Bearing Systems in the Precambrian Belt of Southern Cameroon. International Journal of Geosciences, 7, 501-517. https://doi.org/10.4236/ijg.2016.74038

[107] Soh Tamehe, L., Ganno, S., Nono Kouankap, G.D., Ngnotue, T., Kankeu, B. and Nzenti, J.P. (2014) Stream Sediment Geochemical Survey of Gouap-Nkollo Prospect, Southern Cameroon: Implications for Gold and LREE Exploration. American Journal of Mining and Metallurgy, 2, 8-16.

[108] Teutsong, T., et al. (2016) Petrography and Geochemistry of the Mesoarchean Bikoula Banded Iron Formation in the Ntem Complex (Congo Craton), Southern Cameroon: Implications for Its Origin. Ore Geology Reviews, 80, 267-288. https://doi.org/10.1016/j.oregeorev.2016.07.003

[109] Ganno, S., et al. (2018) Geochemical Constraints on the Origin of Banded Iron Formation-Hosted Iron Ore from the Archaean Ntem Complex (Congo Craton) in the Meyomessi Area, Southern Cameroon. Resource Geology, 68, 287-302. https://doi.org/10.1111/rge.12172

[110] Faure, S. (2012) Potentiel de mineralisations de type IOCG en contexte intracratonique ou d'arcs continentaux dans les terrains archeens et proterozoiques du Quebec. Project 2010-08.

[111] Seltmann, R., Porter, T.M. and Piranjo, F. (2014) Geodynamics and Metallogeny of the Central Eurasian Porphyry and Related Epithermal Mineral Systems: A Review. The Journal of Asian Earth Sciences, 79, 810-841. 
https://doi.org/10.1016/j.jseaes.2013.03.030

[112] Aye, B.A., Sababa, E. and Ndjigui, P. (2017) Geochemistry of S, Cu, Ni, Cr and $\mathrm{Au}-\mathrm{PGE}$ in the Garnet Amphibolites from the Akom II Area in the Archaean Congo Craton, Southern Cameroon. Chemie der Erde-Geochemistry, 77, 81-93.

https://doi.org/10.1016/j.chemer.2017.01.009

[113] Knipping, J.L., Bilenker, L.D., Simon, A.C., Reich, M., Barra, F. and Deditius, A.P. (2015) Giant Kiruna-Type Deposits Form by Efficient Flotation of Magmatic Magnetite Suspensions. Geology, 43, 591-594. https://doi.org/10.1130/G36650.1

[114] Roberto, S., Hühn, B. and Silva, A.M. (2018) Favorability Potential for IOCG Type Deposits in the Riacho do Pontal Belt: New Insights for Identifying Prospects of IOCG-Type Deposits in NE Brazil. Brazilian Journal of Geology, 48, 703-719. https://doi.org/10.1590/2317-4889201820180029 